\title{
CONSTRUCTION OUTPUT MODELLING: A SYSTEMATIC REVIEW
}

\section{ABSTRACT}

Purpose: Construction economics scholars have emphasised the importance of construction output forecasting and have called for increased investment in infrastructure projects, due to the positive relationship between construction output and economic growth. However, construction output tends to fluctuate over time. Excessive changes in the volume of construction output have a negative impact upon the construction sector, such as liquidation of construction companies and job losses. Information gleaned from extant literature suggests that fluctuation in construction output is a global problem. Evidence indicates that modelling of construction output provides information for understanding the factors responsible for these changes.

Methodology: An interpretivist epistemological lens is adopted to conduct a systematic review of published studies on modelling of construction output. A thematic analysis is then presented and the trends and gaps in current knowledge are highlighted.

Findings: It is observed that interest rate is the most common determinant of construction output. Also revealed is that- very little is known about the underlying factors stimulating growth in the volume of investment in maintenance construction works. Further work is required to investigate the efficacy of using non-linear techniques for construction output modelling.

Originality: This study provides a contemporary mapping of existing knowledge relating to construction output and provides insights into gaps in current understanding that can be explored by future researchers.

Keywords: Construction output, forecasting, modelling, systematic review, text mining.

\section{INTRODUCTION}

The construction industry produces a nation's infrastructure in order to support economic growth. For several decades, research has demonstrated that the construction industry is also one of the main drivers of economic growth (Turin, 1978; Dang and Low, 2011; Chiang et al., 2015). Because ofte this causal relationship between construction sector activities and economic growth, academics and practitioners have called for increased investment in construction projects (Anaman and Osei-Amponsah, 2007; Kofoworola and Gheewala, 2008). H however, such investment has not always resulted in economic prosperity and- Fthere are two 
main reasons for this observation. First, there may be athe lack of local capacity to meet the increased demand for new construction projects (cf. Bhalla and Edmonds, 1983; Lewis, 1984). Second, an unplanned increase in investment creates a fluctuation in construction output, which has a negative impact upon the construction sector (Ofori et al., 1996).

Construction output is one metric used forin measuring the volume of construction investment. The fluctuation of construction output is a topical area of interest within the field of construction economics and several models have been developed to identify the factors which affect its volume. This interest stems from the impact of construction output on employment, property prices and construction costs (Jin and Zeng, 2004; Zheng et al., 2012; Saks, 2008; Soo and Oo, 2014). Due to the negative impact that fluctuations in construction output have on the economy, $\mathrm{Ng}$ et al. (2009) suggest that econometric models should be developed to predict future changes in construction output volume. If a model is capable of accurately predicting the volume of construction output, then the critical determinants can be manipulated to produce the desired output. For instance, the impact of intervention strategies could be evaluated in a controlled laboratory (i.e. the model) before implementation. The outcome of model-based studies would provide evidence-based knowledge for minimising the impact of changes iin construction output volume. Although an accurate forecast of an event is essential, it is difficult to achieve this in the real world (Makridakis et al., 2009). The occurrence of a natural disaster would result in drastic changes in the volume of investment in construction works. The huge uncertainty associated with economic and business activities can also affect the accuracy of model forecasts.

Construction output modelling research is targeted at either 'explanation' (see Anaman and Osei-Amponsah, 2007) or 'forecasting' (see Jiang and Liu, 2014). Typically, models are developed for construction output forecasting are based on empirical evidence of the existing relationship between construction activities and the economy (see Riggleman, 1933; Lewis, 1960). Based on the foregoing, socio-economic variables (such as population and interest rates) are used as predictors of construction output. Thus, researchers strive to identify the 'best' set of socio-economic variables to explain or predict movements in the volume of construction output.

\section{Research rationale}

The empirical knowledge-base required to drive an academic discipline is generated through research. According to Runeson (2011), the process of knowledge creation passes 
through three distinct phases: description, explanation and prediction. At the description phase, studies are designed to describe an event in construction practice. Riggleman (1933) describes the fluctuations in the volume of construction output from 1875 to 1932. Subsequently, many studies have examined the relationship between the variations in the volume of construction output and the economy (Turin, 1978; Bon and Minami, 1986). Findings emanating from the description phase inform the choice of variables included in explanatory and prediction models developed in the second and third phases of knowledge creation. Professor Ranko Bon (1992) conducted several studies aimed at understanding the relationship between construction activities and the economy (i.e. explanatory phase). The outcome of these studies informed the hypothesis which states that at an advanced stage of development, the volume of new construction work would reduce and the amount of maintenance construction would be expected to increasegrow due to the needs of ageing infrastructure (ibid). Consolidation of the results from explanatory research leads to the emergence of theories, which then provide a sound base for the development of forecasting models.

Modelling-oriented studies are either used to explain the relationship between two theoretical constructs (e.g. the link between the construction industry and the economy) or for forecasting (see Shmueli and Koppius, 2011). For example, Chiang et al. (2015) report on the development of a model for evaluating the relationship between 'construction output' and the 'economy', and find that a bi-causal relationship exists between the two constructs. In contrast, Sing et al. (2015) use the vector auto-regression (VAR) model for forecasting the volume of private sector investment in construction works. Explanatory modelling is primarily concerned with the building and testing of theories (Runeson, 2011). In contrast, forecasting-oriented research is focused on using established theories to solve practical problems (Shmueli and Koppius, 2011). In cases where forecast models generate unreliable results, the theory upon which the model was built must needs to-be discarded or modified.

Despite the significant effectee that construction output has upon an economy (see Anaman and Osei-Amponsah, 2007; Dang and Low, 2011), studies that focus upon developing models to predict its changes are few. Evidence from literature shows that fluctuations in the volume of construction output areis a recurring problem in several countries, including: Singapore (Goh, 1996), Hong Kong (Sing et al., 2015) and the United Kingdom (Tanratanawong and Scott, 2000). As identified in previous studies, the negative consequences of fluctuating 
construction output volume include: inefficiency in the production process (Ofori et al., 1996); bankruptcy; and retrenchment within the construction industry during periods of low production (Jiang et al., 2013; Ng et al., 2008). Therefore, construction output forecast models provide an understanding of its predictors. This evidence-based information is required for developing strategies to mitigate the impact of construction output fluctuation.

Although Dang and Low (2011) report upon a review of studies exploring the relationship between construction output and the economy, hitherto-, no comprehensive review on construction output forecasting has been published. This current study therefore builds upon the earlier review (ibid) byut undertakesing a systematic review of published studies on construction output modelling and forecasting. Note, those explanatory modelling studies within the scope of the research conducted by Dang and Low (2011) are excluded. Specifically, the review provides answers to the following questions: (i) when and where were the construction output modelling studies published?; (ii) where are construction output modelling studies published?; (iii)-what are the-methods are employedused for construction output modelling?; (iiiv) what has beenis_the focus of previous studies on construction output modelling research?; (iv) which variables are the determinants of construction output?; (vi) what is the relative performance of models used for construction output forecasting? and (vii) what are the key findings exposed by the reviewis the focus of previous studies on construction output modelling? This study contributes to existing knowledge in the field of construction management by: (i) mapping the existing construction output modelling intellectual territory; and (ii) speculating upon the research-opportunities for future researchquestions that can be explored in the future based on the observed gaps in contemporary knowledge. The consolidation and organisation of the literature on construction output modelling will provide valuable insights to various stakeholders (such as policymakers and researchers).

\section{CONSTRUCTION OUTPUT}

Construction output is the monetary value of all construction works executed in a country atover a defined period (usually quarterly). There are variances in the process of collecting and presenting the-data on construction output and its determinants from country to country. For instance, the Census and Statistics Department of Hong Kong views construction output as the "total gross value of construction works performed by main contractors" at a defined time 
(Census and Statistics Department, 2015). Similarities exist between this definition and that of the UK Office of National Statistics (ONS) of the UK-(see Office for National Statistics, 2015), but it is important to note that the ONS deducts value-added tax from the value of construction works. Despite these differences, construction output is a valid measure for quantifying the volume of activities in the construction market at a defined time.

Several metrics are used to quantify the volume of construction output, for example: gross output (Fan et al., 2010); the gross floor area of development commenced (Goh, 1999); and value of construction approvals (Jiang and Liu, 2014). Despite these variances, Ofori (1990) affirms that gross output is an accurate reflection of the volume of activities in the construction industry, because it is the monetary value of developments which clients are willing and able to pay for (i.e. effective demand). Furthermore, Akintoye and Sommerville (1995) find that a lagged relationship exists between 'demand' and _Eeffective demand' for construction works, which suggests that demand for construction works eventually translates to -effective demand(i.e. construction output) at a later date. While a variety of metrics exist for measuring the volume of construction output, it is evident that gross output is an objective measure of the volume of activities within the construction sector.

\section{Disaggregation of construction output}

The need to unmask the factors responsible for changes in the volume of investment in construction works has led to its disaggregation. Although some authors report upon models for construction output at an aggregate level (cf. Jiang and Liu, 2011), others disaggregate construction output into its constituent parts, for instance; based upon the market sectors of manufacturing (Nicholson and Tebbutt, 1979), commercial (Akintoye and Skitmore, 1994) and residential (Goh, 1996). Disaggregation of construction output is targeted at identifying the factors' changes within the factors that affect in the volume of activities in the various segments of the construction market.

\section{Construction output modelling: an overview}

Modelling of construction output provides answers to the following questions: (i) what are the underlying factors responsible for fluctuation in the volume of construction output?; (ii) can existing theories found in literature be used to explain the movements in the volume of 
construction output?; and (iii) can the changes in the volume of construction output be predicted based on existing theories? As stated by Shmueli and Koppius (2011), forecasting is useful for evaluating the practical relevance of theories found in the literature, thus studies focused on modelling contribute to the creation of knowledge.

The first published study on construction output modelling was carried out by Duffy (1975) with further investigations undertaken in subsequent years (cf. Goh, 1996; Jiang and Liu, 2014). Building on the work carried out by Duffy (1975), researchers use several techniques for construction output modelling. As stated in the research rationale-section, model research is either used for 'explanation' or 'prediction' and the processes of developing explanatory and predictiveen models are distinct. Shmueli and Koppius (2011) assert that data partitioning is one of the main differences between explanatory and prediction models. For explanatory models, the model is estimated using the whole dataset. In contrast, studies focused on forecasting partition the collected data is partitioned-into two groups in studies focused on forecasting (one group is used for estimating the model, and the other group is used for validating the model).

Another distinction between the techniques used for modelling of construction output is the type of relationship presumed between the variables. In the earlier research studies years, it was assumed that a linear relationship exists_s_-between construction output and its determinants, an-This_assumption is-responsible for the use of regression in previous research-on construction output modelling (Duffy, 1975). However, the lagged relationship between variables was often overlooked (Goh, 1996). The earlier methods are therefore called 'static' models, whereas in contrast, models that capture contemporaneous and lagged relationships between variables are termed 'dynamic' models. For a detailed explanation on the distinction between static and dynamic models refer to Flood and Issa (2009). The need to address the gap in knowledge has led to the application of several techniques for construction output.

\section{RESEARCH METHODOLOGY}

This research employeds an interpretivist epistemological lens to undertake the literature review. Interpretivism is an established philosophical stance employed within construction management literature and has been successfully employed to, for example ${ }_{2} \div$ review post occupancy evaluation (Roberts et al., 2019); and automateing construction manufacturing procedures using BIM digital objects (BDOs) (Al-Saeed et al., 2020). Several types of literature 
review (e.g. critical review, integrative, systematic, etc.) have been previously published. However, the findings drawn from certain types of review studies are difficult to replicate and may be questionable due to the lack of detailed information aboutregarding the research approach (e.g. sampling approach and inclusion criteria). As a proven method, a_systematic literature review, as a proven method,-_-was adopted in this study to integrate the existing knowledge and a gainfor a deeper understanding of the research problem (Tranfield et al., 2003; Golizadeh et al., 2020). Although a generally accepted guideline for reporting systematic reviews does not exist, Booth (2006) recommends providing information using the "'STARLITE’" mnemonic (i.e. sampling strategy, type of study, approaches, range of years, limits, inclusion and exclusions, terms used, electronic sources).

Many researchers have utilised the systematic review approach in the field of construction management, for example it has been used to highlight the current state of knowledge on drivers of green building (Darko et al., 2017), practice-based learning (Kokkonen and Alin, 2015) and public-private partnership (Ke et al., 2009). Empirical evidence has shown that the systematic review approach integrates existing knowledge about a research problem into a meaningful whole. In the current study, it was used to gain insights into the extant literature on construction output modelling. The systematic review was carried out in two phases, - iz: phase 1 being the database search and screening (search results were screened using the selection and inclusion criteria); and phase 2 being the content analysis of the selected papers.

\section{Scope of the Research Outputs Covered in this Study}

The sample for this study is-comprised of manuscripts published in academic journals only. The reasons for limiting the search to academic journal articles awere that: (i) the outcome of studies reported in conference papers were updated and published as journal articles at a later date; and (ii) the outcome of unpublished works were published as journal papers, for instance, the outcome of an Australian PhD study on construction demand forecasting (Jiang, 2013) was published in two journal papers (Jiang and Liu, 2011; Jiang and Liu, 2014).

\section{Identification of Search Keywords for Database Search}

As suggested in Tranfield et al. (2003), a scoping study was carried out to identify suitable search keywords. The initial search was undertaken using the ARCOM (Association of 
Researchers in Construction Management) database. Two terms, i.e. “_construction output”- and "- "construction demand, ,- were utilised for this initial search. These terms were used to satisfy the objective of the current study and because they are used interchangeably within the literature. The need to identify relevant phrases for the extensive database search was the main reason for this initial exploration. A total of 19 (18 journal and 1 conference) articles were uncovered from the ARCOM database search.

Ananiadou et al. (2009) suggest the use of term extraction, which is a text mining technique, to identify relevant keywords for a systematic literature review. In this study, the TerMine software (Frantzi et al. 2000) was used for term extraction. The title, keywords and abstract of the 19 articles, from the ARCOM search wereas used to create a corpus for term extraction. At the end of the term extraction process, "-construction output'”, "- "construction

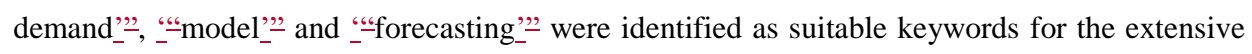
database search.

\section{Search Process}

The systematic process used to search for relevant articles was carried out in three phases (see Figure 1). In phase one, a search was carried out using the SCOPUS and Web of Science [WOS] databases. Several lines of evidence indicate that SCOPUS is a comprehensive database of journals when compared to WOS, CSA Illumina, Microsoft Academic and Google Scholar (Norris and Oppenheim, 2007; Siguenza-Guzman et al., 2015; Hug and Brändle, 2017). As suggested in Baykoucheva (2010), the extensive literature search was carried out on both the SCOPUS and WOS database, The use of these two databases-ensuringed that the search covered a comprehensive range of publication outlets.

InAt phase two, an additional search was carried out on the database of key journals. Previous systematic literature reviews have shown that the use of a combination of indexed and journal database searches ensures that relevant articles are captured (Ke et al., 2009; Kokkonen and Alin, 2015). Due to the multidisciplinary nature of construction output research, an additional search was conducted on journals related to the eovering the following academic disciplines: (i) construction management; and (ii) real estate.

$\underline{\text { InAt }}$ phase three, textual data (titles, abstracts and keywords) relating to papers identifiedfound in the second phasestage were entered in the TerMine software. The data was 
analysed to check iffor any new keywords will be-identified and these. The new keywords were used for an additional search on the SCOPUS and WOS databases. This robust search strategy ensureds that all the relevant articles were identified at the end of the search process.

\section{Phase One The Search-(phase one)}

The combination of keywords used for the database search weare: (i) "“construction

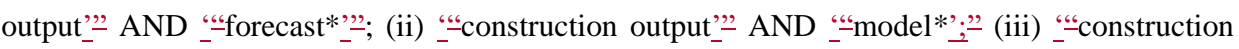

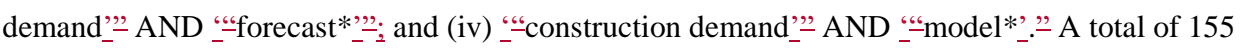
journal articles were identifiedfound at the end of the database search (111 articles from SCOPUS and 44 articles from WOS). An initial screening of search results was undertaken to remove duplicates and irrelevant papers (i.e. papers not within the scope of the review). It was observed that there were numerous duplicates in the search results which wasand this is due to the overlap in the journals indexed in both databases. At the end of the database search and initial screening, 23 relevant journal papers were identified.

\section{The Search-(pPhase Ttwo $\underline{\text { Search }})$}

Construction output research is predominantly published in construction management and real estate journals. In the field of construction management, an additional search was conducted on the databases of the following journals: Construction Management and Economics; Journal of Construction Engineering and Management; Journal of Management in Engineering; Engineering, Construction and Architectural Management; Habitat International; Construction Economics and Building; International Journal of Construction Management; Building and Environment; and Building Research and Information. In the field of real estate, a supplementary search was conducted on the databases of the following journals: Real Estate Economics; Journal of Real Estate Finance and Economics; Journal of Real Estate Research; Journal of Property Finance; Journal of Property Valuation and Investment and Journal of Property Research.

The choice of these journals was informed by the following: (i) the ranking of the journal in the selected field (for details of ranking of construction management and real estate journals, refer to: Wing, 1997; Newell et al., 2002; and Hardin III et al., 2006); relevant papers found in the journal at the end of the SCOPUS and WOS search. At the end of the second search (journal database search), 14 relevant articles were identified. 
PThe Search-(phase Tthree Search)

Formatted: Indent: Left: $0 \mathrm{~cm}$, Hanging: $1.27 \mathrm{~cm}$

The titles, abstracts, and keywords of the 14 articles identified, from $t$ in the second phasestage of the search, were used to create a corpus. This corpus was analysed in the TerMine software and additional keywords were identified for the third phase of the stage of -search

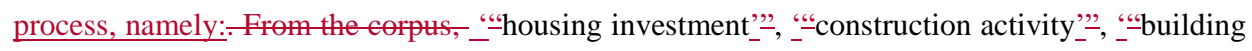
supply”-", "-construction supply'”, and "“property market”" were identified. These keywords were used to carry out an additional search on the SCOPUS and WOS databases. The search process was repeated several times (the stage was done in three phases)-to ensure that a comprehensive list of relevant journal papers was identified. 13 journal papers were found during phase three.

\section{Screening and Collation of the Search Results}

At the completion of the search process, a total of 50 articles were identified (i.e. $23+14+13=50$ journal articles). An initial screening was used to remove irrelevant articles from the search results. Out of the 155 articles found in the phase one, 133 journal papers were excluded from the search results for the following reasons: (i) duplication [articles were found twice or more in the search results]; (ii) inappropriate focus of article subject matter [e.g. construction cost forecasting); and (iii) replication, where studies were covered in the scope of a previous review on relationships between construction output and economic growth (Dang and Low, 2011). In addition, screening was completed at the end of the second and third phase of the search. The filtering (screening) phase of articles entailed a brief review of the journal paper(s) titles and abstracts found in the search results.

Subsequently, the full-text of the 50 articles was assessed for eligibility for inclusion into the study sample. Two unrelated articles were excluded from the outcome of the comprehensive search process. The secondary data (48 journal articles) was collected using the methods previously described and subjected to further analysis. In terms of time, there were no published articles on construction output modelling and forecasting before 1975 and the search reported in this paper was undertaken in 2019. Thus, the scope of the search covered the time period between 1975 and 2019; albeit, no papers published in 2019 meet the inclusion criteria (see 
Table 1). This search criteria ensured that a comprehensive list of relevant journal papers wasere identified during the search process.

Table 1 presents an overview of previous studies selected for this review. In this study, qualitative content analysis was used to dissect the selected journal papers. As suggested in Decrop (1999) and Edwards and Holt (2010), the use of methodological triangulation improves the reliability of findings derived from qualitative research. Subsequently, a data driven approach was used to analyse the title and abstract of each publication. Text mining was used for the analysis and visualisation of the text (i.e. the corpus created using the title, abstract and keywords). The findings emerging from the use of both methods was triangulated.

\section{'Insert Table 1 here' \\ 'Insert Figure 1 here'}

\section{RESULTS}

Detailed information relating to journal papers selected for this study areis presented in Table 1 , thatwhich reveals that a large number of studies have have-focused on modelling of residential construction output and that most. Also, studies found in literature-have largely focused on countries in the developed world (e.g. UK, US, Australia and Singapore).

The results of this study are remaining six constitnent parts of this section were-structured to address the research questions stated in the research rationale subsection ${ }_{2}$ viz: (i): to provide an insights into the number of papers published annuallyin each year for construction output modelling, together with the journal outlets used-for construction output modelling; (ii) to present the modelling techniques used in previous research; (iii) to illustrate the research themes addressed in previous studies; (iv) to identify the determinants (i.e. predictors used to explain or predict movement in the volume of construction output) of construction output; (v) to determine the relative performance of construction output forecast models; and (vi) to summarise the study's key findings.

\section{Construction Output Modelling Research: Annual Publication Trend and Journal outlet}

The content of this subsection addresses the first and second research question stated in the opening section of this paper. A comprehensive literature search-of literature revealed that 
there were 48 articles that focused on construction output modelling, - were published in various journals. These manuscripts were published in various journals, 24 in total, journals, as presented in Table 2. In terms of numbers of published papers, the top-four outlets for disseminating construction output modelling studies were: Construction Management and Economics:- The

Journal of Real Estate Finance and Economics;; Journal of Property Research and Engineering,; and Construction and Architectural Management represent the top four outlets for disseminating construction output modelling studies.

The need to understand factors (i.e. determinants) responsible for fluctuations in the volume of construction output necessitated the study. Despite the importance of construction output modelling, little attention has been paid to this area of research (see Figure 2) (see Figure z). It is visible that there has been an inconsistent trend in the number of construction output modelling studies published between 1975 and 2019. Scant research in this area could be attributed to the non-availability of data in some countries, as observed in previous research (K'Akumu, 2007; Yitmen et al., 2012). Unavailability of data on construction output and its determinants makes it impossible to estimate construction output models. As shown in Figure 2, there is an inconsistent trend in the number of construction output modelling studies that were published between 1975 and 2019.

'Insert Table 2 here'

'Insert Figure 2 here'

\section{Modelling Techniques}

The third research question sought to identify the methods used for modelling of eenstruction output.Several modelling techniques are used to explain and/or predict the changes in the volume of construction output. These techniques used for modelling of construction output eancan be classified based on: (i) the-number of variables included in the model [multivariate and univariate], (ii) consideration of the temporal characteristics of data [time series and nontime series] and (iii) academic discipline [statistical and artificial intelligence]. In some cases, it is difficult to ascribe a modelling technique to one particular category; this. This pitfall can be attributed to the overlap in the label assigned to each modelling approach. For example, the BoxJenkins model is a statistical, univariate (i.e. captures the relationship between the current and 
previous values of construction output) and time-series based approach. In contrast, a vector error correction model is a multivariate technique that captures the relationship between construction output and its determinants. In addition, a vector error correction model is a statistical and time-series based approach.

\section{'Insert Table 3 here'}

A classification summary of tTable 4 shows that thehe descriptive statistics that relateing to modelling techniques used in previous research and the purpose of the study are displayed in Table 4. As stated previously, 48 construction output modelling studies were published in various journals. Offm these studies, 13 models were estimated to explain the relationship between construction output and other input variables, whilst $A 1 s,-35$ models were used to generate forecasts of construction output. In some studies, models are estimated for explanation and forecasting purposes. For example, Fan et al. (2011) estimated a model that explains $40 \%$ of the variations in the volume of construction output. Subsequently, the estimated model was used to generate forecasts of construction output. In terms of the number of variables included in the developed model, multivariate models weare the predominant technique used for modelling of construction output, with 50 instances of utilisation as compared to 19 for univariate models. Jiang and Liu (2011) developed two multivariate models, VEC and VEC-D, for forecasting of Australia's construction output. The popularity of multivariate models may be due to the need to identify underlying reasons for the changes in the volume of construction output. The output of multivariate models helps to identify the determinants (predictors) of construction output.

Based on time consideration, 31 non-time series and 38 time series techniques were used for construction output modelling. Between 1975 and 1983, it was observed that no consideration was given to a temporal relationship among variables during the process of developing construction output models (Duffy, 1975; Nicholson and Tebbutt, 1979; Thomas and Stekler, 1979; Thomas and Stekler, 1983). In recent years (2012-2019), there has been a shift towards the use of time series techniques in construction output modelling research. Statistical techniques (vis-à-vis artificial intelligence techniques) werehave been found to be the predominant method used in construction modelling research. The prevalence of this approach can be linked to its ability to explain the strength of the relationship between construction output 
and its determinants. For instance, Chiang et al. (2015) found that a bi-causal relationship exists between gGross $\underline{\mathrm{d}}$ Đomestic pProduct and construction output.

\section{'Insert Table 4 here'}

\section{Construction Output Modelling: Research Themes and Topics}

Various topics have been investigated in construction output modelling research. As stated in Ofori (1990), the determinants of construction output tend to vary across the-different segments of the construction market. The need to understand the determinants of construction output in each market segment has led to a disaggregation of construction output into its constituent parts. Authors, such as Hillebrandt (1985) and Ofori (1990), have thematically classified construction output into (for example) housing, industrial, commercial and maintenance. For this In th studyis paper, construction output wasis classified based on the content of the published studies selected for the review.

Figure $\underline{3} z$ shows that construction output can be disaggregated into the and classificationsed into various main and subgroups, namely: industry/regional (total, regional); project financier (private, public); and market sector (residential, commercial, manufacturing, maintenance, others, structures and facilities). Some previouspast research endeavours focused on the modelling of two or more types of construction output. For example, Akintoye and Skitmore (1994) developed forecast models for residential, commercial and industrial construction output. This disaggregation is vital for gaining insights into the determinants of each segment.

\section{'Insert Figure $2 \underline{3}$ here'}

\section{Determinants of construction output}

Table 4 reveals that multivariate techniques are frequently used for construction output modelling.-Multivariate models provide insights into the underlying determinants responsible for changes in the volume of construction output and Table 4 reveals their frequent use for construction output modelling. The identification of 'best' determinants is essential for the application of multivariate techniques to construction output modelling. Historically, several 
multivariate techniques have been used for construction output modelling and as ase consequencetly, a large number of determinants (i.e. input variables) of construction output have been identified (see Table 5)..

Table 5 stmmarises the determinants (i.e. input variables) used for construction-output modelling in previous studies. Since construction output tends to fluctuate over time, there is a need to understand the underlying reasons for these cycles. Mitigating the adverse effect of fluctuating construction output is impossible without identifying the determinants that cause changes in its volume. A whole range of determinants (e.g. interest rate and unemployment rate) could influence the volume of construction output as shown in Table 5. However, a closer examination of these previous studies indicates that the determinants ef construction output-vary when different classes of construction output are compared. As suggested in Jiang and Liu (2015), the determinants of construction output were therefore allocatedgrouped into five groups, namely: price; income and production; demography and labour force; customer's' expectations; and other factors. Based on the classification of construction output presented inf_Figure 2$)$, the determinants werecontent of $t$ alsohis subsection is _ p presented according to the under three classications ofheadings, namely: 'pro" "preject financier"-', "_market sector"-' and “industry/regional_.” A summary table of the 48 modelling studies mapped against the classifications is presented in Table 6.

\section{'Insert Table 5 here'}

\section{Project financier}

Based on the eriteria of 'project financier'-classification, construction output can be disaggregated into 'public_and 'private'(Figure 3). Two of the studies that employed multivariate models werehave been developed for 'private' construction output (Ng et al., 2011; Sing et al., 2015). In terms of frequency, the state of the economy, which is a proxy of GDP/GNP/NI, iwas the most common determinant of private construction output (Table 5). In contrast, little is known about the determinants of 'public' construction output because no multivariate model(s) have been estimated for it. However, it must be noted that there were univariate models were estimated for public construction output (Public $\mathrm{t}_{\mathrm{t}+1}$ ) forecasting in Lam and Oshodi (2016a). These univariate models used information contained in its current $\left(\right.$ Public $_{t}$ ) and past values (Public $\left.\mathrm{t}_{-1}\right)$. 


\section{Market Sector}

In terms of market sector, construction output can be disaggregated into the following components: residential, commercial, manufacturingindustry, maintenance, structures and facilities and 'others' (Figure 3). From Tables 1 and 6, it can be seen that 30 studies reported the development of models for 'residential' construction output (e.g. Akintoye and Skitmore, 1994; Goh, 1996). In contrast, the modelling of “_structure and facilities"' and 'maintenance' construction output received the least attention in published studies. In terms of frequency, interest rate (12 studies), construction price index (nine studies) and population (nine studies) were the most common determinants of residential construction output.

In relative terms, the number of multivariate models were-developed for 'commercial_' (nine studies) and 'manufacturing' construction output (ten studies) are similar. The most common determinants of 'commercial' construction output are "interest rate", "property value", "state of the economy" and "retail sales". In contrast, "state of the economy", "interest rate", "unemployment rate", "property value", "total production", "national savings" and "manufacturing output" are the prevalent determinants of manufacturing construction output. This finding suggests that the determinants of construction output in different segments of the market are unique.

\section{Industry/regional}

The data presented in Table 6 shows that 11 models were used for modelling of construction output at the 'industry' (overall) level, whilst i- In contrast, only one study was carried out en modelling of construction-output-at 'regional' level (Jiang and Liu, 2014). "Interest rate", "unemployment rate" and "state of the economy" are the most cited determinants of overall construction output. Usually, large volumes of financial resources are expended during the process of procuring construction projects. Hence, clients and project sponsors may need to source loans from banks and other financial institution for the execution of their projects. As a result, changes in interest rates and the state of the economy (GDP) are positively related to construction output. This assertion iwas validated in Fan et al. (2011) whose work reveales GDP and interest rates play a role in determining the volume of construction output.

\section{'Insert Table 6 here'}




\section{The relative performance of construction output forecast models}

As explained by Shmueli and Koppius (2011), the processes for- $\bullet$ f validating explanatory and prediction models are distinct. For explanatory models, strength of fitness is the primary metric used to evaluate the developed model, whereas the accuracy of the out-of-sample forecast is the measure for validating predictive models. For instance, Jiang and Liu (2011) collected data covering the period from 1996Q3 to 2010Q2. The data series covering 1996Q3 to 2009Q2 was used for model estimation and subsequently, the developed model was used to generate the outof-sample forecast for the last four data points from 2009Q3 to 2010Q2. In the out-of-sample period, the forecast values were compared with the actual values of construction output.

-Error variance (i.e. the difference between the actual and forecasted value of construction investment) is used to quantify the uncertainty of anthe estimated model. In the field of construction economics, forecast errors are computed using percentage error (PE), mean squared error (MSE), mean percentage error (MPE), mean absolute percentage error (MAPE), Theil's inequality coefficient $(U)$, root mean squared error (RMSE) and index sum (IS).

\section{'Insert Table 7 here'}

\section{Summary of results}

Seven interesting findings emanated from this research. First, a total of 48 studies were published between 1975 and 2019, although it should be . It is imperative to-noted that no study was published on this topic in 2019 itself. Second, previous construction modelling studies have predominantly focused on countries located in the Northern hemisphere, for example Previous eonstruction output modelling studies-(Table 1) have foeused on the UK (Duffy, 1975; Tanratanawong and Scott, 2000), USA (Thomas and Stekler, 1979; Fullerton et al., 2001), Australia (Jiang and Liu, 2011), Singapore (Goh, 1996) and Hong Kong (Fan et al., 2011) among others. Third, from the data in Table 4, multivariate and statistical techniques were identified asare the dominant tools used in construction modelling research.

Fourth, interest rate, state of the economy (GDP/GNP/NI), unemployment rate, population, construction price index, national savings and rent were found to be popular determinants of construction output (Table 5). The use of a subjective variable, such as the occurrence of global financial crisis, washas been limited to two studies (Jiang and Liu, 2011; 
Jiang et al., 2013). Fifth, little is known about the determinants of certain classes of construction output. This finding is due to the development of a limited number of models for those classes of construction output. For example, Tanratanawong and Scott (2000) is the only study to apply multivariate techniques to maintenance construction output (cf. Table 5 $\underline{3}$ ). Thus, little is known about the determinants of maintenance and public construction output. Sixth, it is apparent from Table 7 that statistical models provide reliable forecasts of construction output. However, a comparison shows that the artificial intelligence models outperform statistical models in terms of predictive performance.

Finally, a data driven approach, i.e. text mining, was used to verify the findings emanating from the review of the selected journal papers. The title, abstract and keywords of the selected papers were used to construct a corpus. Due to the absence of abstracts, two publications (i.e., Duffy, 1975; Nicholson and Tebbutt, 1975) were not added to the corpus. The corpus was analysed using the $\mathrm{R}$ programming software (R Core Team, 2015) to generate the most frequent terms found within itin the corpus. In terms of frequency of occurrence, the top 20 words are presented in Figure 4. The five most frequent words in the corpus are model, construction, forecast, construction output and housing. There are similarities between the findings obtained from the content analysis and data-driven text analysis. For example, the data presented in Table 4 shows that most construction output modelling studies focused on forecasting. This convergence indicates that the study is credible and robust.

\section{'Insert Figure 4 here'}

\section{DISCUSSION OF FINDINGS}

Models are used to unmask the underlying factors responsible for fluctuations in the volume of construction output. This study has undertaken a systematic review of the published studies on construction output modelling and aA summary of the main findings has beenwere presented. The following discussion highlights further several key results that were raised by the $r$-in the previous subsection. In this section, the results of this study. raise several key issues which are discussed in subsequent paragraphs.

One interesting finding is that socio-economic variables [such as GDP, interest rate and unemployment rate, among others] are the predominant determinants of construction output. 
This study supports the evidence presented in previous research (Turin, 1978; Anaman and OseiAmponsah, 2007), which showed that construction output and economic growth are positively related. As stated earlier, finding the right balance between construction output and the capacity of the construction sector is quintessentially important for developing strategies to mitigate the impact caused by changes in volume. For example, a contracting firm could decide to seek overseas opportunities based on an envisaged drop in the volume of construction output.

It was found that few studies focused on construction output modelling. There are several possible explanations for this result. The unavailability of data could be one limiting factor. ef the reasons limiting the interest in construction output modelling. Studies have shown that the quantity and quality of construction statistics is inadequate in certain countries (K'Akumu, 2007). To address this, there is a need to identify alternative metrics for quantifying the volume of construction activities. For instance, Gruneberg and Folwell (2013) demonstrate that the construction component of gross fixed capital formation (GFCF) could be used as a substitute for construction output. Based on the information available from World Bank, data on GFCF is relatively available in most countries (World Bank, 2019). The adoption of GFCF would make it easier to develop models for construction output in several countries.

Terms associated with forecasting are popular in construction modelling publications (see Figure 3). This finding suggests that construction output modelling is at the third stage of knowledge creation. In most of the previous published studies, authors fail to explicitly state the theory which informed the choice of variables in model developmentused to develop models. Runeson and de Valence (2015) assert that the main weakness of most studies in the field of construction economics stems from the failure to utilise existing theories. However, it must be mentioned here-that most of the variables included in construction modelling studies are informed by findings from previous research. Comparison between the findings of construction modelling studies is useful for validity and refuting of existing theories.

Statistical techniques are the most commonly used tool employedapproach for construction output modelling - quite possibly because of the imperative need to understand the relationship between-e confstruction output and its determinants. However,Seme issues were observed in some previous construction output modelling studies which used statistical techniques. First, non-stationary variables were included in some of the-statistical models. T; this may be partly responsible for the high value of R-square reported in thesesome previous studies, 
f. For example- the R-square value of one of the models estimated in Tang et al. (1990) is 0.96. The observed relationship could be attributed to spurious regressions (Brooks, 2014). Second, some statistical models provide little or no information about the relationship between construction output and its determinants. Despite being atheoretical, univariate models are proven to be useful for modelling and forecasting construction output (Goh and Teo, 2000; Fan et al., 2010). Hence, researchers need to find the right balance between theory and model fit when estimating construction output models. This claim stems from the fact that some atheoretical models are useful in practice.

Lastly, it was revealed that the non-linear techniques (such as ANN and SVM) tend to generate a more reliable forecast of construction output when compared with linear models. This result is consistent with those reported in earlier studies (Weron, 2014). Flexibility and lack of explanatory information are two main weaknesses of non-linear models. The effect of each determinant on construction output is unknown; this is the main reason for naming this class of techniques as 'black box' models. In practice, the management of fluctuation in the volume of construction output is not entirely dependent on the accuracy of forecast models. However, the theory, policy and practice implications of this research are potentially far reaching. From a theoretical perspective, the range of models reviewed illustrates academia's inimitable attempts to further refine, fine-tune and improve the accuracy of models produced. This partly acknowledges the fact that forecasting models are often limited to short term forecasts (typically three to five years) and subject to perturbations in macro-economic conditions. From a political perspective, models can be used as a simulation laboratory (so called economic levers) for evaluating the impact of competing policies on the predicted variable (Ogunlana et al., 2003). From a supply chain perspective, For example, government may, for example, relax immigration laws to attract foreign workers due to a projected increase in the volume of construction activities. Alternatively, government interventions to lower taxation or inflation rates can trigger business growth and home purchasing which in turn stimulates: the aggregates sector to produce more raw materials; the manufacturing sector to build more construction products; and Also, construction equipment manufacturers to build more machinery to cater for booming demand. Of course the converse is true, but the construction and civil engineering sector is inextricably $\underline{\text { linked to national wealth which underscores the importance of accurate prediction models. In }}$ practice, an accurate forecast is essential to industry who must fine-tune investments in key 
resources so as to expand operations when markets are buoyant (and capitalise on market growth), and contract operations when in a recession, to preserve the business in readiness to capitalise upon future expansion. could use information provided by construction output forecasts to develop strategies for product sales. These practical implications of forecasting market elasticity indicates that the reliability of construction output forecasting is vital for various stakeholders and athe national economy.

\section{Paths for future research}

TIn the previous section, the published studies on construction output modelling were hitherto consolidated. This compression of information provides details on the trends and gaps in the-current knowledge within this area. Based on the gaps identified, the directions for future construction output modelling studies are speculated. The four main topics which emerged ${ }_{2}$ in the preceding sections, either explicitly or implicitly, are -as follows:

1) Selection of 'best' input variables (determinants) for the estimation of construction output models has become increasing important (cf. Jud and Winkler, 2003). Although the current study indicates that a large set of macroeconomic variables (e.g. interest rates and population) affects the volume of construction output, there is a need to identify the best 'set' of determinants. This information would ease the process of calibrating construction output models and this-is vital for identifying the optimal set of variables.

2) The determinants of construction output were found to vary from sector to sector (see Table 3). Ofori (1990) asserts that the determinants of construction output in the different segments of the construction market are unique, whilst Bon (1992) contends that the dynamic nature of the construction sector is also influential. This suggests that the determinants of construction output vary at different stages of development, and across countries, which demonstrates the need to understand the underlying causes of fluctuations in construction output volume in various segments of the construction maarket. Although multivariate models have been estimated for construction output in the different segments of the construction market, little is known about the changes in certain market sectors (Table 3). For example, there have been limited studies on modelling of public, private and maintenance construction output. These areas should be explored in future studies. 
3) Hithertoenceforth, the inclusion of dummy variables in models used for forecasting construction output has been limited to four previous research studies (viz: Thomas and Stekler, 1979; Thomas and Stekler, 1983; Jiang et al., 2013; Jiang and Liu, 2011). The addition of a dummy variable, representing the global financial crisis, improved the reliability of construction output forecasts in a-previous research (Jiang and Liu, 2011). Alaka et al. (2016) suggest that the inclusion of subjective data into models would result in reliable predictions and in this case, would improve the understanding of the effects of these factors on construction output. For instance, the government of Hong Kong introduced the mandatory building inspection scheme (MBIS) and mandatory window inspection scheme (MWIS) in 2012 (Tan et al., 2012). The policy is targeted at stimulating growth in the volume of maintenance works. The effect of this policy (including other similar interventions) on the volume of maintenance construction output needs to be investigated. However, the inclusion of these non-traditional determinants of construction output into models must be adequately justified.

4) The application of contemporary techniques to construction output modelling research needs to be explored. For example, interrupted time series models couldan be used to evaluate the impact of policies (e.g. MWIS and MBIS (ibid)) on changes in the volume of construction output. Research in the field of artificial intelligence has shown that the potential of using text mining for prediction (Nassirtoussi et al., 2014). However, the use of these techniques has not been explored in construction output modelling research. In future investigations, it might be possible to use text mining to predict public construction output.

5) Evaluation of the quality of the construction output model is important. The purpose of the study is the main criteria for deciding on the approach used to evaluate the developed model. Shmueli and Koppius (2011) proffer that the coefficient of determination and errors (variances between actual and forecast values) are the metrics for evaluating explanatory and forecast models, respectively. MAPE and $U$ coefficient are popular metrics used for evaluating construction output forecastsing models (Fan et al., 2011; Jiang and Liu, 2014). However, the limitations of these measures have resulted in the development of new metrics for evaluating forecast accuracies (Hyndman and Koehler, 
2006), such as the mean absolute scaled error. The use of these new metrics could improve the process of validating construction output models.

\section{CONCLUSION}

Modelling offers a useful approach for unveiling the determinants that account for the changes in the volume of construction output. The main goals of this current study wereas to systematically review the literature on construction output modelling andbut also-raise the importance of accurate modelling, s-not only for industry practitioners but also the wider national economy. The study has found that macro-economic variables are significant predictors of the volume of construction output but finer nuances between the way that data is reported in various countries means that a singular 'one-shoe-fits-all' global model is unlikely to be achieved. Residential construction output modelling has been the main focus of numerous previous research studies, while significantly less attention has been paid to modelling of maintenance and public construction output. Also, the inadequacies of certain techniques used for construction output modelling were highlighted. In this regard, construction output modellers can benefit from the advances that are being made in the field of statistics and computer science.

The findings of this study have theoretical and practical implications. In several countries across the globe, governments are implementing strategies to stimulate construction activities. The impact of these interventions (such as MBIS in Hong Kong and Help to Bbuy scheme in the UK) are currently unknown. Thise outeome of this study provides a comprehensive list of determinants that can be used infor futurethe construction output model -development $\theta f$ eonstruction-output models-for evaluating the impact of these intervention programs, and alsoThe outcome of this study provides insight into the trends and gaps in the current knowledge on construction output modelling. This information could serve as justification for future studies within this area. Reduced volatility in the volume of construction output is important due to its causal relationship with employment, equipment sales and economic development (Chiang et al., 2015; Holt and Edwards, 2012). An understanding of the determinants of construction output could help stakeholders anticipate changes in its volume and develop appropriate strategies for responding to such events.

Several limitations to the current study must be acknowledged. First, the study's sample was limited to papers published in academic journals. Second, the search was limited to 
academic papers published in English. Thus, relevant papers published in other languages (such as Chinese and Spanish) were excluded from the study. Notwithstanding these limitations, the objectives of the present study were achieved. Five research gaps were identified, namely: (i) the need for an objective approach for identifying the 'best' variables for modelling of construction output; (ii) a lack of studies that focused on maintenance and public construction output modelling; (iii) lack of consideration for inclusion of subjective factors in construction output models; (iv) the need for a greater use of contemporary techniques in construction output modelling; and (v) the need to use robust metrics for evaluating the predictive accuracy of construction output models. Further studies must be conducted to address these identified gaps. 


\section{REFERENCES}

Akintoye, A. and Skitmore, M. (1994). Models of UK private sector quarterly construction demand. Construction Management and Economics, 12(1), 3-13.

Akintoye, A. and Sommerville, J. (1995). Distributed lag relationships between UK construction orders and output. Construction Management and Economics, 13(1), 33-42.

Alagidede, P. (2016). On the temporary and permanent components of global construction. Applied Economics Letters, 23(4), 284-289.

Alaka, H. A., Oyedele, L. O., Owolabi, H. A., Ajayi, S. O., Bilal, M. and Akinade, O. O. (2016). Methodological approach of construction business failure prediction studies: a review. Construction Management and Economics, 34(11), 808-842.

Al-Saeed, Y., Edwards, D. and Scaysbrook, S. (2020) Automating construction manufacturing procedures using BIM digital objects (BDOs): Case study of knowledge transfer partnership project in UK, Construction Innovation, Vol. ahead-of-print No. ahead-ofprint. DOI: https://doi.org/10.1108/CI-12-2019-0141

Ananiadou, S., Rea, B., Okazaki, N., Procter, R. and Thomas, J. (2009). Supporting systematic reviews using text mining. Social Science Computer Review, 27(4), 509-523.

Anaman, K. A. and Osei-Amponsah, C. (2007). Analysis of the causality links between the growth of the construction industry and the growth of the macro-economy in Ghana. Construction Management and Economics, 25(9), 951-961.

Ball, M. and Grilli, M. (1997). UK commercial property investment: Time-series characteristics and modelling strategies. Journal of Property Research, 14(4), 279-296.

Ball, M. and Tsolacos, S. (2002). UK commercial property forecasting: the devil is in the data. Journal of Property Research, 19(1), 13-38.

Baykoucheva, S. (2010). Selecting a database for drug literature retrieval: a comparison of MEDLINE, Scopus, and Web of Science. Science and Technology Libraries, 29(4), 276288.

Benjamin, J. D., Jud, G. D. and Winkler, D. T. (1995). An analysis of shopping center investment. The Journal of Real Estate Finance and Economics, 10(2), 161-168.

Berg, L. and Berger, T. (2006). The Q theory and the Swedish housing market —an empirical test. The Journal of Real Estate Finance and Economics, 33(4), 329-344. 
Bhalla, A. S. and Edmonds, G. A. (1983). Construction growth and employment in developing countries. Habitat International, 7(5-6), 195-206.

Bon, R. (1992). The future of international construction: secular patterns of growth and decline. Habitat International, 16(3), 119-128.

Bon, R. and Minami, K. (1986). The role of construction in the national economy: a comparison of the fundamental structure of the US and Japanese input-output tables since World War II. Habitat International, 10(4), 93-99.

Booth, A. (2006). " Brimful of STARLITE": toward standards for reporting literature searches. Journal of the Medical Library Association, 94(4), 421-429.

Brooks, C. (2014). Introductory Econometrics for Finance. 3rd ed. Cambridge: Cambridge University Press.

Census and Statistics Department (2015). Report of Quarterly Survey of Construction Output (4th Quarter 2014). Hong Kong: Census and Statistics Department, Government of Hong Kong SAR.

Chang, C. O. and Linneman, P. (1990). Forecasting housing investment in developing countries. Growth and Change, 21(1), 59-72.

Chiang, Y. H., Tao, L. and Wong, F. K. W. (2015). Causal relationship between construction activities, employment and GDP: The case of Hong Kong. Habitat international, 46, 112.

Dang, T. H. G. and Low, S. P. (2011). Role of construction in economic development: Review of key concepts in the past 40 years. Habitat International, 35(1), 118-125.

Darko, A., Zhang, C. and Chan, A. P. C. (2017). Drivers for green building: A review of empirical studies. Habitat international, 60, 34-49.

Decrop, A. (1999). Triangulation in qualitative tourism research. Tourism management, 20(1), 157-161.

Duffy, M. (1975). On the short-term forecasting of private housing investment in the United Kingdom. Applied Economics, 7(2), 119-134.

Edwards, D. J. and Holt, G. D. (2010) The case for '3D triangulation' when applied to construction management research. Construction Innovation, 10(1), 25-41.

Elíasson, L. (2017). Icelandic boom and bust: immigration and the housing market. Housing Studies, 32(1), 35-59. 
Fan, R. Y. C., Ng, S. T. and Wong, J. M. W. (2010). Reliability of the Box-Jenkins model for forecasting construction demand covering times of economic austerity. Construction Management and Economics, 28(3), 241-254.

Fan, R. Y. C., Ng, S. T. and Wong, J. M. W. (2011). Predicting construction market growth for urban metropolis: An econometric analysis. Habitat International, 35(2), 167-174.

Fergus, J. T. (1999). Where, when, and by how much does abnormal weather affect housing construction?. The Journal of Real Estate Finance and Economics, 18(1), 63-87.

Flood, I. and Issa, R. R. A. (2009). Empirical modeling methodologies for construction. Journal of Construction Engineering and Management, 136(1), 36-48.

Frantzi, K., Ananiadou, S. and Mima, H. (2000). Automatic recognition of multi-word terms. International Journal of Digital Libraries, 3(2), 117-132

Fullerton, T. M., Laaksonen, M. M. and West, C. T. (2001). Regional multi-family housing start forecast accuracy. International Journal of Forecasting, 17(2), 171-180.

Giussani, B. and Tsolacos, S. (1994). Investment in industrial buildings: modelling the determinants of new orders. Journal of Property Research, 11(1), 1-15.

Goh, B. H. (1996). Residential construction demand forecasting using economic indicators: a comparative study of artificial neural networks and multiple regression. Construction Management and Economics, 14(1), 25-34.

Goh, B. H. (1998). Forecasting residential construction demand in Singapore: a comparative study of the accuracy of time series, regression and artificial neural network techniques. Engineering, Construction and Architectural Management, 5(3), 261-275.

Goh, B. H. (1999). An evaluation of the accuracy of the multiple regression approach in forecasting sectoral construction demand in Singapore. Construction Management and Economics, 17(2), 231-241.

Goh, B. H. (2000). Evaluating the performance of combining neural networks and genetic algorithms to forecast construction demand: the case of the Singapore residential sector. Construction Management and Economics, 18(2), 209-217.

Goh, B. H. (2012). Modeling sectoral construction demand and its relationship with economic indicators. International Journal of Construction Education and Research, 8(3), 223-240. 
Goh, B. H. and Teo, H. P. (2000). Forecasting construction industry demand, price and productivity in Singapore: the Box-Jenkins approach. Construction Management and Economics, 18(5), 607-618.

Golizadeh, H., Hosseini, M. Reza., Martek, I., Edwards, D.J., Gheisari, M., Banihashemi, S. and Zhang, J. (2020) Research on 'remotely piloted aircraft' in the construction industry: a research agenda for the construction industry, Engineering, Construction and Architectural Management. Vol. ahead-of-print No. ahead-of-print. DOI: https://doi.org/10.1108/ECAM-02-2019-0103

Gruneberg, S. and Folwell, K. (2013). The use of gross fixed capital formation as a measure of construction output. Construction Management and Economics, 31(4), 359-368.

Hillebrandt, P. M. (1985). Economic Theory and the Construction Industry. 2nd ed. Hong Kong: Macmillan.

Holt, G. D. and Edwards, D. J. (2012). Analysis of United Kingdom off-highway construction machinery market and its consumers using new-sales data. Journal of Construction Engineering and Management, 139(5), 529-537.

Hug, S. E. and Brändle, M. P. (2017). The coverage of Microsoft Academic: Analyzing the publication output of a university. Scientometrics, 113(3), 1551-1571.

Hyndman, R. J. and Koehler, A. B. (2006). Another look at measures of forecast accuracy. International Journal of Forecasting, 22(4), 679-688.

Jiang, H. (2013). Econometric techniques for estimating construction demand in Australia. PhD, Deakin University.

Jiang, H., Jin, X. H. and Liu, C. (2013). The effects of the late 2000s global financial crisis on Australia's construction demand. Construction Economics and Building, 13(3), 65-79.

Jiang, H. and Liu, C. (2011). Forecasting construction demand: A vector error correction model with dummy variables. Construction Management and Economics, 29(9), 969-979.

Jiang, H. and Liu, C. (2014). A panel vector error correction approach to forecasting demand in regional construction markets. Construction Management and Economics, 32(12), 12051221.

Jiang, H. and Liu, C. (2015). Identifying determinants of demand for construction using an econometric approach. International Journal of Strategic Property Management, 19(4), 346-357. 
Jin, Y. and Zeng, Z. (2004). Residential investment and house prices in a multi-sector monetary business cycle model. Journal of Housing Economics, 13(4), 268-286.

Jud, G. D. and Winkler, D. T. (2003). The Q theory of housing investment. The Journal of Real Estate Finance and Economics, 27(3), 379-392.

K'Akumu, O. A. (2007). Construction statistics review for Kenya. Construction Management and Economics, 25(3), 315-326.

Kagochi, J. M. and Kiambigi, M. (2012). Remittances' Influence on Housing Construction Demand in Sub-Saharan Africa: The Case of Kenya. African Development Review, 24(3), 255-265.

Karamujic, H. M. (2012). Modelling seasonality in Australian building approvals. Construction Economics and Building, 12(1), 26-36.

Ke, Y., Wang, S., Chan, A. P. C. and Cheung, E. (2009). Research trend of public-private partnership in construction journals. Journal of Construction Engineering and Management, 135(10), 1076-1086.

Kofoworola, O. F. and Gheewala, S. (2008). An input-output analysis of Thailand's construction sector. Construction Management and Economics, 26(11), 1227-1240.

Kokkonen, A. and Alin, P. (2015). Practice-based learning in construction projects: a literature review. Construction Management and Economics, 33(7), 513-530.

Lam, K. C. and Oshodi, O. S. (2016a). Forecasting construction output: a comparison of artificial neural network and Box-Jenkins model. Engineering, Construction and Architectural Management, 23(3), 302-322.

Lam, K. C. and Oshodi, O. S. (2016b). Using Univariate Models for Construction Output Forecasting: Comparing Artificial Intelligence and Econometric Techniques. Journal of Management in Engineering, 32(6), 04016021.

Lewis, J. P. (1960). Building cycles: a regional model and its national setting. The Economic Journal, 70(279), 519-535.

Lewis, T. M. (1984). A review of the causes of recent problems in the construction industry of Trinidad and Tobago. Construction Management and Economics, 2(1), 37-48.

Ma, L., Liu, C. and Reed, R. (2017). The impacts of residential construction and property prices on residential construction outputs: an inter-market equilibrium approach. International Journal of Strategic Property Management, 21(3), 296-306. 
Ma, L., Reed, R. and Jin, X. (2018). Identify the equilibrium of residential construction output: A vector error correction model approach. Engineering, Construction and Architectural Management, 25(1), 21-38.

Makridakis, S., Hogarth, R. M. and Gaba, A. (2009). Forecasting and uncertainty in the economic and business world. International Journal of Forecasting, 25(4), 794-812.

Nassirtoussi, A. K., Aghabozorgi, S., Wah, T. Y. and Ngo, D. C. L. (2014). Text mining for market prediction: A systematic review. Expert Systems with Applications, 41(16), 76537670.

Newell, G., Acheampong, P., Juchau, R., Wing, C. K. and Webb, J. (2002). An international analysis of real estate journals. Journal of Property Investment and Finance, 20 (6), 454472.

Ng, S. T., Chan, A. P. C., Chiang, Y. H., Kumaraswamy, M. M., Lam, P. T. I., Lee, P. K. K., et al. (2008). Reinventing the Hong Kong Construction Industry for its Sustainable Development. Hong Kong: Final Report Submitted to the Construction Industry Institute - Hong Kong.

Ng, S. T., Fan, R. Y., Wong, J. M. W., Chan, A. P. C., Chiang, Y. H., Lam, P. T. I., et al. (2009). Coping with structural change in construction: experiences gained from advanced economies. Construction Management and Economics, 27(2), 165-180.

Ng, S. T., Fan, R. Y. C. and Wong, J. M. W. (2011). An econometric model for forecasting private construction investment in Hong Kong. Construction Management and Economics, 29(5), 519-534.

Nicholson, R. J. and Tebbutt, S. G. (1979). Modelling of new orders for private industrial building. The Journal of Industrial Economics, 28(2), 147-160.

Notman, D., Norman, G., Flanagan, R. and Agapiou, A. (1998). A time-series analysis of UK annual and quarterly construction output data (1955-95). Construction Management and Economics, 16(4), 409-416.

Norris, M. and Oppenheim, C. (2007). Comparing alternatives to the Web of Science for coverage of the social sciences' literature. Journal of informetrics, 1(2), 161-169.

Office for National Statistics (2015). Output in the Construction Industry, January 2015 and New Orders, Quarter 4 October to December 2014. London, UK: Office for National Statistics. 
Ofori, G. (1990). The Construction Industry: Aspects of its Economics and Management. Singapore: Singapore University Press.

Ofori, G., Hindle, R. and Hugo, F. (1996). Improving the construction industry of South Africa: A strategy. Habitat International, 20(2), 203-220.

Ogunlana, S. O., Li, H. and Sukhera, F. A. (2003). System dynamics approach to exploring performance enhancement in a construction organization. Journal of Construction Engineering and Management, 129(5), 528-536.

R Core Team, 2015. R: A language and environment for statistical computing. R Foundation for Statistical Computing, Vienna, Austria.

Riggleman, J. R. (1933). Building cycles in the United States, 1875-1932. Journal of the American Statistical Association, 28(182), 174-183.

Roberts, C. J., Edwards, D. J., Hosseini, M. Reza., Matzeo-Garcia, M. and Owusu-Man, D. (2019) Post occupancy evaluation: a critical review of literature. Engineering, Construction and Architectural Management, 26(9), 2084-2106.

Runeson, G. (2011). The Methodology of Building Economics Research. In: De Valence, G. (ed.) Modern Construction Economics. Oxon, UK: Spon Press.

Runeson, G. and de Valence, G. (2015). A critique of the methodology of building economics: trust the theories. Construction Management and Economics, 33(2), 117-125.

Saginor, J. (2018). The Real Estate Academic Leadership (Real) Rankings For 2014-2018. Journal of Real Estate Literature, 26(2), 255-261.

Saks, R. E. (2008). Job creation and housing construction: Constraints on metropolitan area employment growth. Journal of Urban Economics, 64(1), 178-195.

Shmueli, G. and Koppius, O. R. (2011). Predictive analytics in information systems research. MIS Quarterly, 35(3), 553-572.

Siguenza-Guzman, L., Saquicela, V., Avila-Ordóñez, E., Vandewalle, J. and Cattrysse, D. (2015). Literature review of data mining applications in academic libraries. The Journal of Academic Librarianship, 41(4), 499-510.

Sing, M. C. P., Edwards, D. J., Liu, H. J. X. and Love, P. E. D. (2015). Forecasting private-sector construction works: VAR model using economic indicators. Journal of Construction Engineering and Management, 141(11), 04015037. 
Sklarz, M. A., Miller, N. G. and Gersch, W. (1987). Forecasting Using Long-Order Autoregressive Processes: An Example Using Housing Starts. Real Estate Economics, 15(4), 374-388.

Somerville, C. T. (1999). Residential construction costs and the supply of new housing: endogeneity and bias in construction cost indexes. The Journal of Real Estate Finance and Economics, 18(1), 43-62.

Soo, A. and Oo, B. L. (2014). The effect of construction demand on contract auctions: an experiment. Engineering, Construction and Architectural Management, 21(3), 276-290.

Tan, Y., Langston, C., Wu, M. and Ochoa, J. J. (2015). Grey forecasting of construction demand in Hong Kong over the next ten years. International Journal of Construction Management, 15(3), 219-228.

Tan, Y., Shen, L. and Langston, C. (2012). A casual relationship between building maintenance market and GDP: Hong Kong study. Journal of Facilities Management, 10(3), 241-251.

Tang, J. C. S., Karasudhi, P. and Tachopiyagoon, P. (1990). Thai construction industry: demand and projection. Construction Management and Economics, 8(3), 249-257.

Tanratanawong, S. and Scott, S. (2000). A neural network model to forecast national construction output. Journal of Financial Management of Property and Construction, $5(1), 65-77$.

Thomas, R. W. and Stekler, H. (1979). Forecasts of construction activity for states. Economics Letters, 4(2), 195-199.

Thomas, R. W. and Stekler, H. O. (1983). A regional forecasting model for construction activity. Regional Science and Urban Economics, 13(4), 557-577.

Thompson, R. and Tsolacos, S. (2000). Projections in the industrial property market using a simultaneous equation system. Journal of Real Estate Research, 19(2), 165-188.

Tranfield, D., Denyer, D. and Smart, P. (2003). Towards a methodology for developing evidence-informed management knowledge by means of systematic review. British Journal Of Management, 14(3), 207-222.

Tsolacos, S. (1995). Industrial property development in the UK: a regional analysis of new orders. Journal of Property Research, 12(2), 95-125.

Turin, D. A. (1978). Construction and development. Habitat International, 3(1-2), 33-45. 
Weron, R. (2014). Electricity price forecasting: A review of the state-of-the-art with a look into the future. International Journal of Forecasting, 30(4), 1030-1081.

Wing, C. K. (1997). The ranking of construction management journals. Construction Management and Economics, 15(4), 387-398.

World Bank. (2019). Gross fixed capital formation (current LCU) [Online]. Available: https://data.worldbank.org/indicator/NE.GDI.FTOT.CN?view=map [Accessed 16 June 2019].

Yitmen, I., Akiner, I. and Marar, K. (2012). Reviewing building construction statistics in Turkey: Stakeholders' perspective. Habitat International, 36(3), pp.371-379.

Zheng, X., Chau, K. W. and Hui, E. C. M. (2012). The impact of property price on construction output. Construction Management and Economics, 30(12), 1025-1037. 
Figure 1 Research fFramework

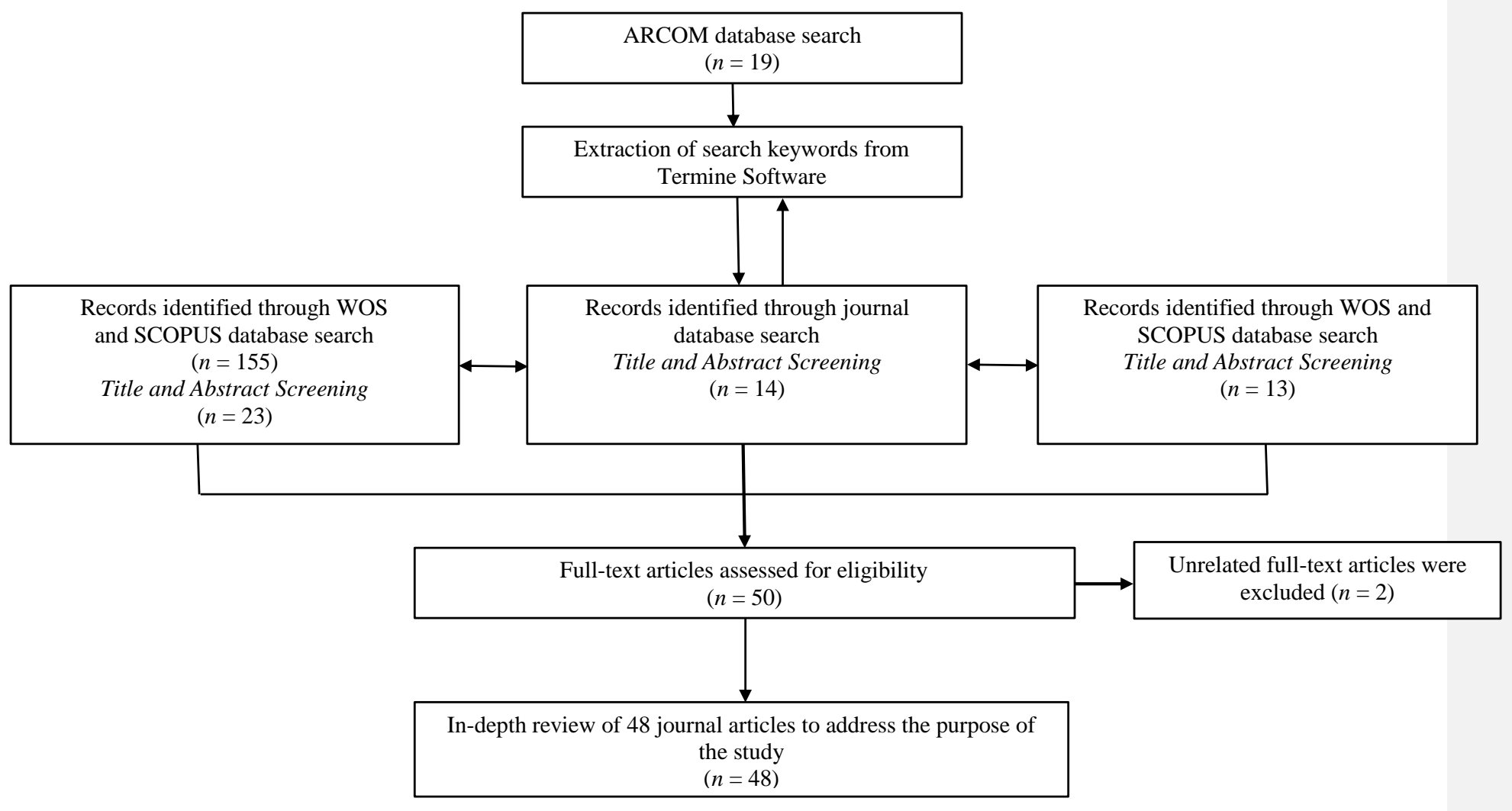


Figure 2: Number of relevant articles published per year

5

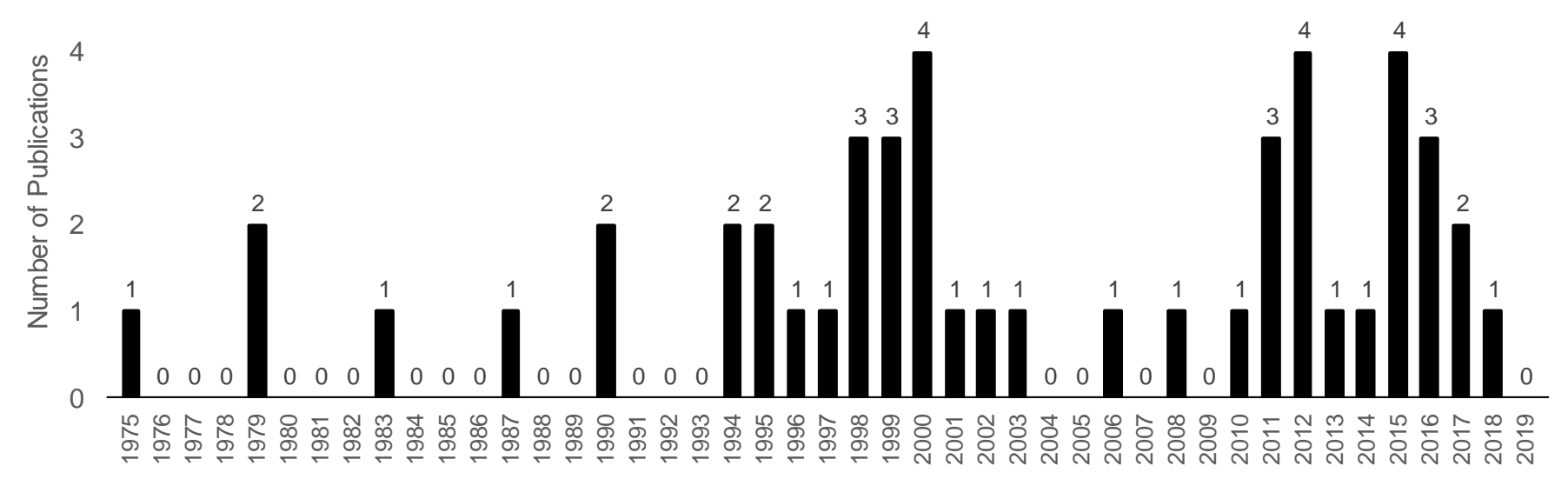

Year 
Figure 3 - An overview of $\underline{c}$ Construction o@ $\underline{\text { ututput }} \underline{\mathrm{c}}$ Classification

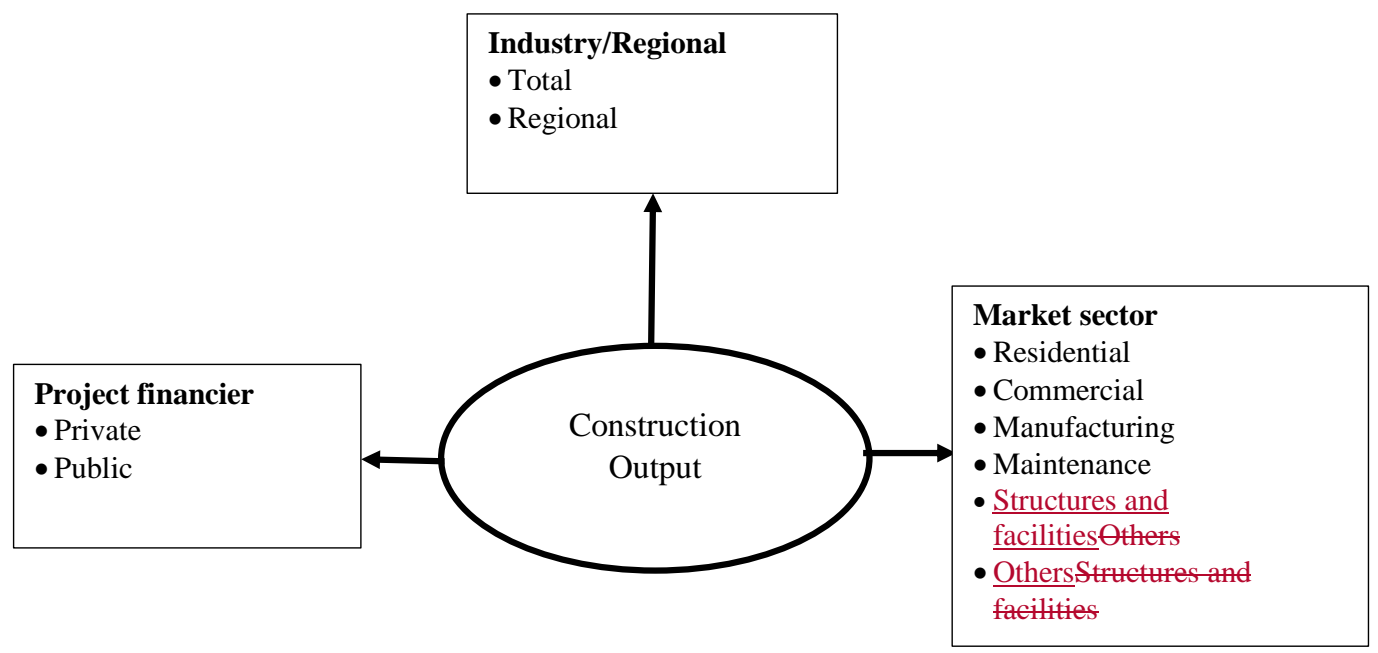


Figure 4 - Term analysis of construction output modelling publications

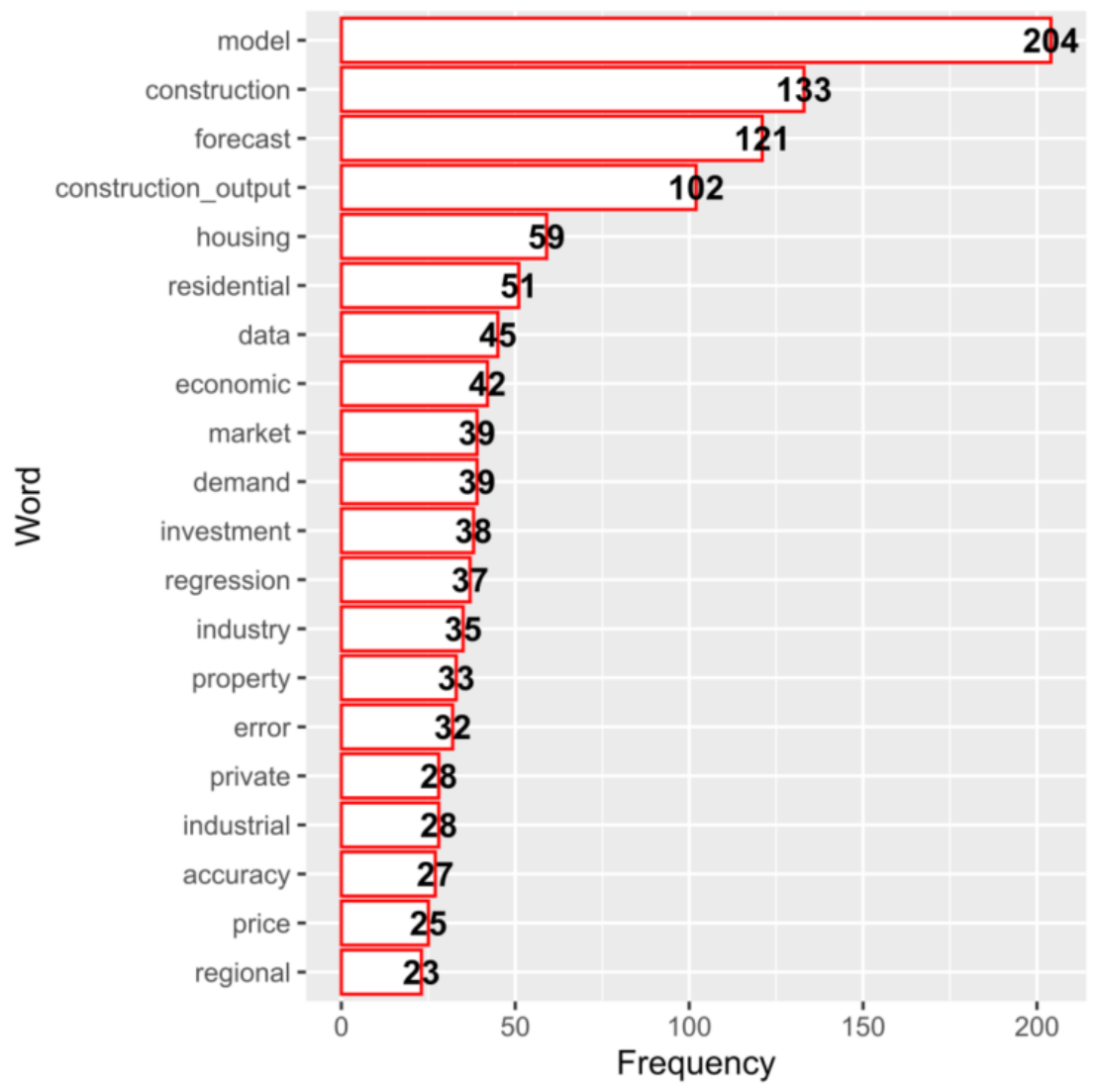


Table 1 - An overview of $\underline{c}$ Construction oOutput $\underline{\text { mModelling } \underline{\underline{s}} \text { Studies }}$

\begin{tabular}{|c|c|c|c|c|}
\hline No. & Author(s) & Country & Output variable(s) & Publication outlet \\
\hline 1 & Duffy (1975) & United-Kingdom (UK) & Residential & Applied Economics \\
\hline 2 & Nicholson and Tebbutt (1979) & UK & Manufacturing & Journal of Industrial Economics \\
\hline 3 & Thomas and Stekler (1979) & United States (USA) & Residential & Economics Letters \\
\hline 4 & Thomas and Stekler (1983) & USA & Residential & Regional Science and Urban Economics \\
\hline 5 & Sklarz et al. (1987) & USA & Residential & Real Estate Economics \\
\hline 6 & Tang et al. (1990) & Thailand & Residential, manufacturing and others & Construction Management and Economics \\
\hline 7 & Chang and Linneman (1990) & $\begin{array}{l}\text { Japan, Korea, Taiwan } \\
\text { and USA }\end{array}$ & Residential & Growth and Change \\
\hline 8 & Akintoye and Skitmore (1994) & UK & Residential, commercial and manufacturing & Construction Management and Economics \\
\hline 9 & Giussani and Tsolacos (1994) & UK & Manufacturing & Journal of Property Research \\
\hline 10 & Benjamin et al. (1995) & USA & Commercial & $\begin{array}{l}\text { The Journal of Real Estate Finance and } \\
\text { Economics }\end{array}$ \\
\hline 11 & Tsolacos (1995) & UK & Manufacturing & Journal of Property Research \\
\hline 12 & Goh (1996) & Singapore & Residential & Construction Management and Economics \\
\hline 13 & Ball and Grilli (1997) & UK & Commercial & Journal of Property Research \\
\hline 14 & Goh (1998) & Singapore & Residential & $\begin{array}{l}\text { Engineering, Construction and } \\
\text { Architectural Management }\end{array}$ \\
\hline 15 & Notman et al. (1998) & UK & Overall & Construction Management and Economics \\
\hline 16 & Tsolacos (1998) & UK & Commercial & Journal of Property Research \\
\hline 17 & Fergus (1999) & USA & Residential & $\begin{array}{l}\text { The Journal of Real Estate Finance and } \\
\text { Economics }\end{array}$ \\
\hline 18 & Goh (1999) & Singapore & Residential, commercial and manufacturing & Construction Management and Economics \\
\hline 19 & Somerville (1999) & USA & Residential & $\begin{array}{l}\text { The Journal of Real Estate Finance and } \\
\text { Economics }\end{array}$ \\
\hline 20 & Goh (2000) & Singapore & Residential & Construction Management and Economics \\
\hline 21 & Goh and Teo (2000) & Singapore & Residential & Construction Management and Economics \\
\hline 22 & $\begin{array}{l}\text { Tanratanawong and Scott } \\
(2000)\end{array}$ & UK & Residential, maintenance and others & $\begin{array}{l}\text { Journal of Financial Management of } \\
\text { Property and Construction }\end{array}$ \\
\hline 23 & Thompson and Tsolacos (2000) & UK & Industrial & Journal of Real Estate Research \\
\hline 24 & Fullerton et al. (2001) & USA & Residential & International Journal of Forecasting \\
\hline 25 & Ball and Tsolacos (2002) & UK & Commercial and manufacturing & Journal of Property Research \\
\hline 26 & Jud and Winkler (2003) & USA & Residential & $\begin{array}{l}\text { The Journal of Real Estate Finance and } \\
\text { Economics }\end{array}$ \\
\hline 27 & Berg and Berger (2006) & Sweden & Residential & The Journal of Real Estate Finance and \\
\hline
\end{tabular}




Ng et al. (2008b)
Fan et al. (2010)
Fan et al. (2011)
Jiang and Liu (2011)
Ng et al. (2011)
Goh (2012)
Karamujic (2012)
Kagochi and Kiambigi (2012)
Zheng et al. (2012)
Jiang et al. (2013)
Jiang and Liu (2014)
Chiang et al. (2015)
Jiang and Liu (2015)
Sing et al. (2015)
Tan et al. (2015)
Alagidede (2016)
Lam and Oshodi (2016a)
Lam and Oshodi (2016b)
Elíasson (2017)
Ma at al. (2017)
Ma at al. (2018)

$\begin{array}{ll}\text { Hong Kong } & \text { Residential } \\ \text { Hong Kong } & \text { Residential, commercial, manufacturing and overal } \\ \text { Hong Kong } & \text { Overall } \\ \text { Australia } & \text { Overall } \\ \text { Hong Kong } & \text { Private } \\ \text { Singapore } & \text { Residential, commercial and manufacturing } \\ \text { Australia } & \text { Residential } \\ \text { Kenya } & \text { Residential } \\ \text { Hong Kong } & \text { Residential and commercial } \\ \text { Australia } & \text { Residential, Non-residential and overall } \\ \text { Australia } & \text { Regional } \\ \text { Hong Kong } & \text { Building, structures and facilities, and overall } \\ \text { Australia } & \text { Overall } \\ \text { Hong Kong } & \text { Private } \\ \text { Hong Kong } & \text { Residential, structures and facilities, maintenance, } \\ \text { Global } & \text { Ond overall } \\ \text { Hong Kong } & \text { Others, private, public and overall } \\ \text { Hong Kong } & \text { Residential, maintenance and overall } \\ \text { Iceland } & \text { Residential } \\ \text { Australia } & \text { Residential } \\ \text { Australia } & \text { Residential } \\ & \end{array}$

Economics

Building and Environment

Construction Management and Economics Habitat International

Construction Management and Economics Construction Management and Economics International Journal of Construction Education and Research

Construction Economics and Building

African Development Review

Construction Management and Economics

Construction Economics and Building

Construction Management and Economics

Habitat International

International Journal of Strategic Property Management

Journal of Construction Engineering and Management

International Journal of Construction

Management

Applied Economics Letters

Engineering, Construction and

Architectural Management

Journal of Management in Engineering

Housing Studies

International Journal of Strategic Property Management

Engineering, Construction and Architectural Management 
Table 2 - Number of relevant manuscripts published in each journal

\begin{tabular}{lrr}
\hline Journal & Number & Percentage \\
\hline Construction Management and Economics & 12 & 25.00 \\
The-Journal of Real Estate Finance and Economics & 5 & 10.42 \\
Journal of Property Research & 5 & 10.42 \\
Engineering, Construction and Architectural Management & 3 & 6.25 \\
International Journal of Strategic Property Management & 2 & 4.17 \\
Habitat International & 2 & 4.17 \\
Construction Economics and Building & 2 & 4.17 \\
Regional Science and Urban Economics & 1 & 2.08 \\
Real Estate Economics & 1 & 2.08 \\
Journal of Real Estate Research & 1 & 2.08 \\
Journal of Management in Engineering & 1 & 2.08 \\
Journal of Industrial Economics & 1 & 2.08 \\
Journal of Financial Management of Property and Construction & 1 & 2.08 \\
Journal of Construction Engineering and Management & 1 & 2.08 \\
International Journal of Forecasting & 1 & 2.08 \\
International Journal of Construction Management & 1 & 2.08 \\
International Journal of Construction Education and Research & 1 & 2.08 \\
Housing Studies & 1 & 2.08 \\
Growth and Change & 1 & 2.08 \\
Economics Letters & 1 & 2.08 \\
Building and Environment & 1 & 2.08 \\
Applied Economics Letters & 1 & 2.08 \\
Applied Economics & 1 & 2.08 \\
African Development Review & 1 & 2.08 \\
\hline
\end{tabular}

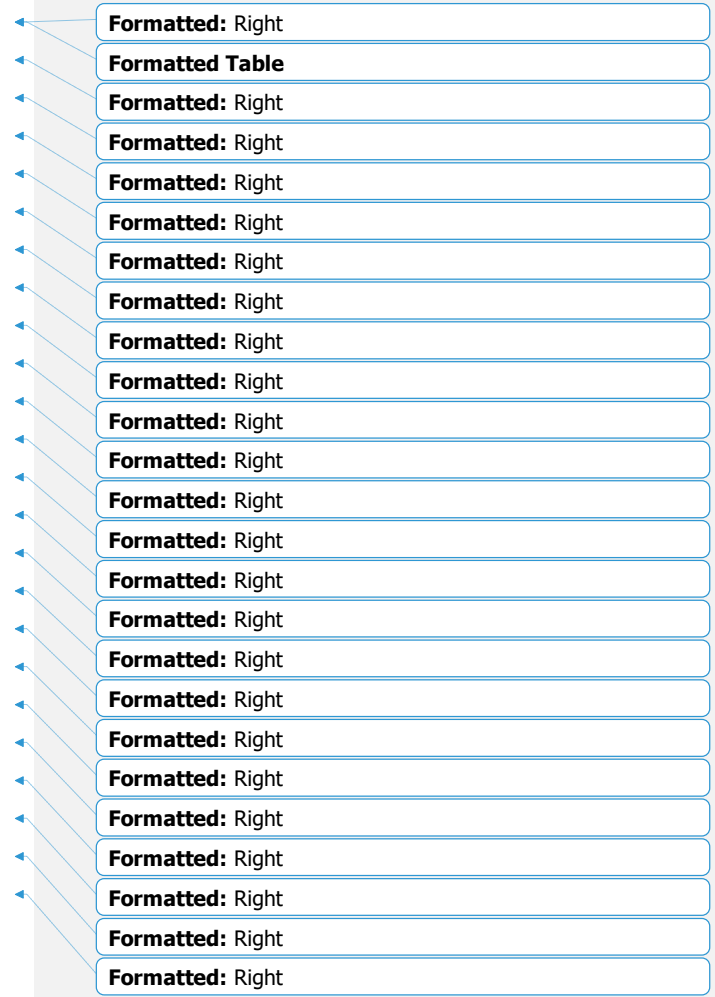


Table 3 - Summary of mModelling tFechniques uUsed in pPrevious rResearch

\begin{tabular}{|c|c|c|c|c|c|c|}
\hline \multirow[t]{2}{*}{ No. } & \multirow[t]{2}{*}{ Study } & \multirow[t]{2}{*}{ Modelling technique } & \multirow[t]{2}{*}{ Focus } & \multicolumn{3}{|c|}{ Classification of technique } \\
\hline & & & & Variables & Time & Discipline \\
\hline 1 & Duffy (1975) & Regression & Forecasting & Multivariate & Non-time series & Statistical \\
\hline 2 & Nicholson and Tebbutt (1979) & Regression & Forecasting & Multivariate & Non-time series & Statistical \\
\hline 3 & Thomas and Stekler (1979) & LSDV & Explanation & Multivariate & Non-time series & Statistical \\
\hline 4 & Thomas and Stekler (1983) & LSDV & Forecasting & Multivariate & Non-time series & Statistical \\
\hline \multirow[t]{2}{*}{5} & Sklarz et al. (1987) & Box-Jenkins & Forecasting & Univariate & Time series & Statistical \\
\hline & & Autoregressive & & Univariate & Non-time series & Statistical \\
\hline 6 & Tang et al. (1990) & Regression & Forecasting & Multivariate & Non-time series & Statistical \\
\hline 7 & Chang and Linneman (1990) & $\begin{array}{l}\text { Box-Jenkins } \\
\text { Trend }\end{array}$ & Forecasting & $\begin{array}{l}\text { Univariate } \\
\text { Univariate }\end{array}$ & $\begin{array}{c}\text { Time series } \\
\text { Non-time series }\end{array}$ & $\begin{array}{l}\text { Statistical } \\
\text { Statistical }\end{array}$ \\
\hline 8 & Akintoye and Skitmore (1994) & Regression & Forecasting & Multivariate & Non-time series & Statistical \\
\hline 9 & Giussani and Tsolacos (1994) & Almon lag polynomial & Explanation & Multivariate & Time series & Statistical \\
\hline 10 & Benjamin et al. (1995) & Regression & Explanation & Multivariate & Non-time series & Statistical \\
\hline 11 & Tsolacos (1995) & Regression & Forecasting & Multivariate & Time series & Statistical \\
\hline \multirow[t]{2}{*}{12} & Goh (1996) & Regression & Forecasting & Multivariate & Non-time series & Statistical \\
\hline & & $\mathrm{NN}$ & & Multivariate & Non-time series & Artificial intelligence \\
\hline 13 & Ball and Grilli (1997) & VAR & Explanation & Multivariate & Time series & Statistical \\
\hline \multirow[t]{3}{*}{14} & Goh (1998) & Box-Jenkins & Forecasting & Univariate & Time series & Statistical \\
\hline & & Regression & & Multivariate & Non-time series & Statistical \\
\hline & & $\mathrm{NN}$ & & Multivariate & Non-time series & Artificial intelligence \\
\hline 15 & Notman et al. (1998) & Box-Jenkins & Forecasting & Univariate & Time series & Statistical \\
\hline 16 & Tsolacos (1998) & Regression & Forecasting & Multivariate & Time series & Statistical \\
\hline 17 & Fergus (1999) & Regression & Explanation & Multivariate & Non-time series & Statistical \\
\hline \multirow[t]{3}{*}{18} & Goh (1999) & Regression & Forecasting & Multivariate & Non-time series & Statistical \\
\hline & & Log-Regression & & Multivariate & Non-time series & Statistical \\
\hline & & ANLR & & Multivariate & Non-time series & Statistical \\
\hline 19 & Somerville (1999) & Regression & Explanation & Multivariate & Non-time series & Statistical \\
\hline \multirow[t]{2}{*}{20} & Goh (2000) & $\mathrm{NN}$ & Forecasting & Multivariate & Non-time series & Artificial intelligence \\
\hline & & GA-NN & & Multivariate & Non-time series & Artificial intelligence \\
\hline 21 & Goh and Teo (2000) & Box-Jenkins & Forecasting & Univariate & Time series & Statistical \\
\hline 22 & Tanratanawong and Scott (2000) & $\mathrm{NN}$ & Forecasting & Multivariate & Non-time series & Artificial intelligence \\
\hline 23 & Thompson and Tsolacos (2000) & Regression & Explanation & Multivariate & Non-time series & Statistical \\
\hline \multirow[t]{2}{*}{24} & Fullerton et al. (2001) & Box-Jenkins & Forecasting & Univariate & Time series & Statistical \\
\hline & & Random walk & & Univariate & Non-time series & Statistical \\
\hline \multirow[t]{2}{*}{25} & Ball and Tsolacos (2002) & Box-Jenkins & Forecasting & Univariate & Time series & Statistical \\
\hline & & Regression & & Multivariate & Time series & Statistical \\
\hline 26 & Jud and Winkle & Regression & Exp & Multivariate & Time series & Statistical \\
\hline 27 & Berg and Berger (2006) & ECM & Explanation & Multivariate & Time series & Statistical \\
\hline
\end{tabular}

\begin{tabular}{ll}
\hline Formatted: Centered \\
\hline Formatted Table \\
\hline Formatted: Left \\
\hline Formatted: Centered \\
\hline Formatted: Centered \\
\hline Formatted: Centered \\
\hline Formatted: Centered \\
\hline Formatted: Centered \\
\hline Formatted: Centered \\
\hline Formatted: Centered \\
\hline Formatted: Centered \\
\hline Formatted: Centered Centered \\
\hline Formatted: Centered \\
\hline Formatted: Centered \\
\hline Formatted: Centered \\
\hline Formatted: Centered \\
\hline Formatted: Centered \\
\hline Formatted: Centered \\
\hline Formatted: Centered \\
\hline Formatted: Centered \\
\hline Formatted: Centered Centered \\
\hline Formatted: Centered \\
\hline
\end{tabular}

41 


\begin{tabular}{|c|c|c|c|c|c|c|}
\hline \multirow[t]{2}{*}{28} & $\mathrm{Ng}$ et al. (2008b) & Regression & Forecasting & Multivariate & Non-time series & Statistical \\
\hline & & GA-Regression & & Multivariate & Non-time series & Artificial intelligence \\
\hline \multirow{2}{*}{29} & Fan et al. (2010) & Box-Jenkins & Forecasting & Univariate & Time series & Statistical \\
\hline & & Regression & & Multivariate & Time series & Statistical \\
\hline \multirow[t]{2}{*}{30} & Fan et al. (2011) & Regression & Forecasting & Multivariate & Time series & Statistical \\
\hline & & VEC & & Multivariate & Time series & Statistical \\
\hline \multirow[t]{2}{*}{31} & Jiang and Liu (2011) & VEC & Forecasting & Multivariate & Time series & Statistical \\
\hline & & VEC-D & & Multivariate & Time series & Statistical \\
\hline \multirow[t]{2}{*}{32} & Ng et al. (2011) & Regression & Forecasting & Multivariate & Time series & Statistical \\
\hline & & VEC & & Multivariate & Time series & Statistical \\
\hline 33 & Goh (2012) & Log-Regression & Forecasting & Multivariate & Non-time series & Statistical \\
\hline 34 & Karamujic (2012) & Structural & Forecasting & Univariate & Time series & Statistical \\
\hline 35 & Kagochi and Kiambigi (2012) & ARDL & Explanation & Multivariate & Time series & Statistical \\
\hline \multirow[t]{2}{*}{36} & Zheng et al. (2012) & ARDL & Forecasting & Multivariate & Time series & Statistical \\
\hline & & ECM & & Multivariate & Time series & Statistical \\
\hline 37 & Jiang and Liu (2013) & VEC & Explanation & Multivariate & Time series & Statistical \\
\hline \multirow[t]{3}{*}{38} & Jiang and Liu (2014) & Regression & Forecasting & Multivariate & Time series & Statistical \\
\hline & & P-OLS & & Multivariate & Time series & Statistical \\
\hline & & P-VEC & & Multivariate & Time series & Statistical \\
\hline 39 & Chiang et al. (2015) & Regression & Explanation & Multivariate & Time series & Statistical \\
\hline 40 & Jiang and Liu (2015) & VEC & Explanation & Multivariate & Time series & Statistical \\
\hline 41 & Sing et al. (2015) & VAR & Forecasting & Multivariate & Time series & Statistical \\
\hline 42 & Tan et al. (2015) & Grey box & Forecasting & Univariate & Non-time series & Statistical \\
\hline 43 & Alagidede (2016) & Structural & Forecasting & Univariate & Time series & Statistical \\
\hline \multirow[t]{2}{*}{44} & Lam and Oshodi (2016a) & Box-Jenkins & Forecasting & Univariate & Time series & Statistical \\
\hline & & NN & & Univariate & Non-time series & Artificial intelligence \\
\hline \multirow[t]{3}{*}{45} & Lam and Oshodi (2016b) & Box-Jenkins & Forecasting & Univariate & Time series & Statistical \\
\hline & & NN & & Univariate & Non-time series & Artificial intelligence \\
\hline & & SVM & & Univariate & Non-time series & Artificial intelligence \\
\hline 46 & Elíasson (2017) & Regression & Forecasting & Multivariate & Non-time series & Statistical \\
\hline 47 & Ma et al. (2017) & P-VEC & Forecasting & Multivariate & Time series & Statistical \\
\hline 48 & Ma et al. (2018) & P-VEC & Forecasting & Multivariate & Time series & Statistical \\
\hline
\end{tabular}

Fored

Note: $\mathrm{ANLR}=$ autoregressive nonlinear regression; $\mathrm{ARDL}=$ autoregressive distributed lag; $\mathrm{ECM}=$ error correction model; $\mathrm{GA}=$ genetic algorithm; LSDV = least squares dummy variables; NN = neural network; P-OLS = panel ordinary least square; P-VEC = panel vector error correction; $\mathrm{SVM}=$ support vector machine; VAR = vector autoregression; VEC = vector error correction; and VEC-D = vector error correction with dummy. 
Table 4 - Descriptive statistics: Classification of modelling techniques

\begin{tabular}{llr}
\hline Criteria & Classification & Number \\
\hline Focus & Explanation & 13 \\
& Forecasting & 35 \\
\hline \multirow{3}{*}{ Variables } & Univariate & \\
& Multivariate & 19 \\
& & 50 \\
\hline \multirow{2}{*}{ Time } & Non-time series & 31 \\
& Time series & 38 \\
\hline \multirow{2}{*}{ Discipline } & Statistical & 60 \\
& Artificial intelligence & 9 \\
\hline
\end{tabular}


Table 5 - Determinants of cEonstruction o@utput

\begin{tabular}{|c|c|c|c|c|c|c|c|c|c|}
\hline $\mathbf{S} / \mathbf{N}$ & Determinant(s) & Residential & Commercial & Manufacturing & Maintenance & S\&F* & Others & Private & Overall 4 \\
\hline & Price & & & & & & & \multirow{9}{*}{ [41] } & \\
\hline 1 & Real price index/relative price index & {$[6,22]$} & & & [22] & & & & \\
\hline 2 & $\begin{array}{l}\text { Construction price index/building tender } \\
\text { price index }\end{array}$ & $\begin{array}{l}{[8,14,18,19,20,33,} \\
37,47,48]\end{array}$ & [13] & [23] & & & [37] & & $\begin{array}{l}{[31,37,38,} \\
40]\end{array}$ \\
\hline 3 & Property price index & {$[12,26,27,28,47]$} & & & & & & & \\
\hline 4 & Consumer price index & {$[12,28]$} & & & & & & & \\
\hline 5 & Commercial land price & & {$[18,33]$} & & & & & & \\
\hline 6 & Rents/property value/property price & {$[26,27,36,48]$} & {$[13,16,36]$} & {$[9,11,23]$} & & & & & [40] \\
\hline 7 & Industrial share prices index & & & [11] & & & & & \\
\hline \multirow[t]{2}{*}{8} & Export/import price index & & & {$[18,33]$} & & & & & [40] \\
\hline & Income and production & & & & & & & & \\
\hline 9 & State of the economy (GDP/GNP/NI) & {$[6,8,12]$} & {$[8,13,25]$} & $\begin{array}{l}{[8,11,18,25,} \\
33]\end{array}$ & & [39] & {$[37,39]$} & {$[32,41]$} & $\begin{array}{l}{[30,38,39,} \\
40]\end{array}$ \\
\hline 10 & Disposable income/national income & {$[3,4,22,37]$} & & & [22] & & {$[22]$} & & {$[37,40]$} \\
\hline 11 & Weekly earnings & & & & & & & & [40] \\
\hline 12 & $\begin{array}{l}\text { Total production/industrial production } \\
\text { index }\end{array}$ & & & {$[6,9,33]$} & [22] & & & & [40] \\
\hline 13 & Productivity & & {$[18,33]$} & {$[18,33]$} & & & & & \\
\hline 14 & Manufacturing profitability & & & {$[8,11]$} & & & & & \\
\hline 15 & National savings/ corporate savings & {$[14,18,20,33]$} & {$[18,33]$} & {$[6,18,33]$} & & & & & [31] \\
\hline 16 & GDP per capita/ GDP (A) at factor cost & {$[7,12,22]$} & & & [22] & & & & \\
\hline 17 & Gross fixed capital formation & $\begin{array}{l}{[12,14,18,20,22,} \\
33]\end{array}$ & & & & & [22] & & \\
\hline 18 & Manufacturing output & & & {$[2,11,18]$} & [22] & & [22] & & \\
\hline 19 & Government revenue & & & & & & [6] & & \\
\hline 20 & Capital expenditure intention & & & [33] & & & & & \\
\hline 21 & Trade balance & & & [33] & & & & & \\
\hline \multirow[t]{2}{*}{22} & Value of export/ imports & [37] & & {$[18,33]$} & & & {$[22,37]$} & & {$[31,37,40]$} \\
\hline & Demography and labour force & & & & & & & & \\
\hline 23 & Population & $\begin{array}{l}{[3,4,6,7,14,18,20,} \\
33,37]\end{array}$ & & {$[18,33]$} & & & {$[37]$} & & {$[31,37,38]$} \\
\hline 24 & Labour cost & [12] & & {$[18,33]$} & & & & & [40] \\
\hline 25 & Rate of new immigration & {$[3,4]$} & & & & & & & \\
\hline
\end{tabular}

26 Consumer's expectations

26 Interest rate 


\begin{tabular}{|c|c|c|c|c|c|c|c|c|}
\hline 27 & Unemployment rate & $\begin{array}{l}18,20,28,33,37] \\
{[12,14,18,20,28} \\
33,37]\end{array}$ & {$[8]$} & {$[11,18,33]$} & & {$[37]$} & {$[32]$} & $\begin{array}{l}38,40] \\
{[31,37,38,} \\
40]\end{array}$ \\
\hline 28 & Consumer expenditure & [22] & {$[16]$} & & & {$[22]$} & & \\
\hline 29 & Final consumption expenditure & [22] & & & [22] & & & \\
\hline 30 & Retail sales & & {$[10,18,33]$} & & & & & \\
\hline 31 & Inflation rate & [7] & & & & & & \\
\hline 32 & Household expenditure & [37] & & & & [37] & & {$[31,37,40]$} \\
\hline 33 & Exchange rate & & & {$[18,33]$} & & & & \\
\hline \multirow[t]{2}{*}{34} & Leading indicators/bank loans & & & [18] & & & & [40] \\
\hline & Other factors & & & & & & & \\
\hline 35 & Vacancy rate/ Vacancy rate (industrial) & & & {$[9,11]$} & & & {$[41]$} & \\
\hline 36 & Capital value indices & & [25] & [25] & & & & \\
\hline 37 & Number of planning approvals & & {$[18,33]$} & & & & & \\
\hline 38 & Depreciation & & & [11] & & & & \\
\hline 39 & Government expenditure & [28] & & & & & & [40] \\
\hline 40 & Total investment/investment intensity & {$[28,46]$} & & {$[18,33]$} & & & [32] & \\
\hline 41 & Money supply & [12] & & [33] & & & & \\
\hline 42 & Money supply (savings and others) & [12] & & & & & & \\
\hline 43 & Volume of pension fund withdrawals & [12] & & & & & & \\
\hline 44 & $\begin{array}{l}\text { Additions in housing stock/ housing } \\
\text { stock }\end{array}$ & $\begin{array}{l}{[3,4,14,18,20,33,} \\
46]\end{array}$ & & & & & & \\
\hline 45 & $\begin{array}{l}\text { Private housing starts/ Private sector: } \\
\text { Housing completion }\end{array}$ & {$[1,22]$} & & & {$[22]$} & {$[22]$} & & \\
\hline 46 & Output index: construction & & & & & [22] & & \\
\hline 47 & Government final consumption & [22] & & & & & & \\
\hline 48 & Gross value added at basic prices & [22] & & & & & & \\
\hline 49 & Household final consumption & [22] & & & & & & \\
\hline 50 & Tax rate & & {$[10]$} & & & & & \\
\hline 51 & Precipitation & [17] & & & & & & \\
\hline 52 & Temperature & [17] & & & & & & \\
\hline 53 & Remittance & [35] & & & & & & \\
\hline
\end{tabular}


Table 6-Summary of classification of construction output modelling studies No.

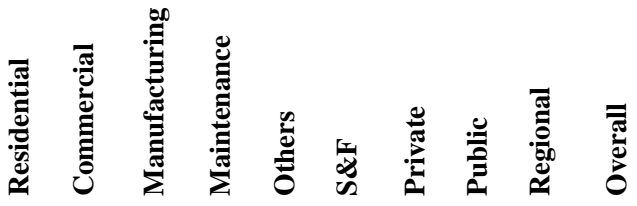

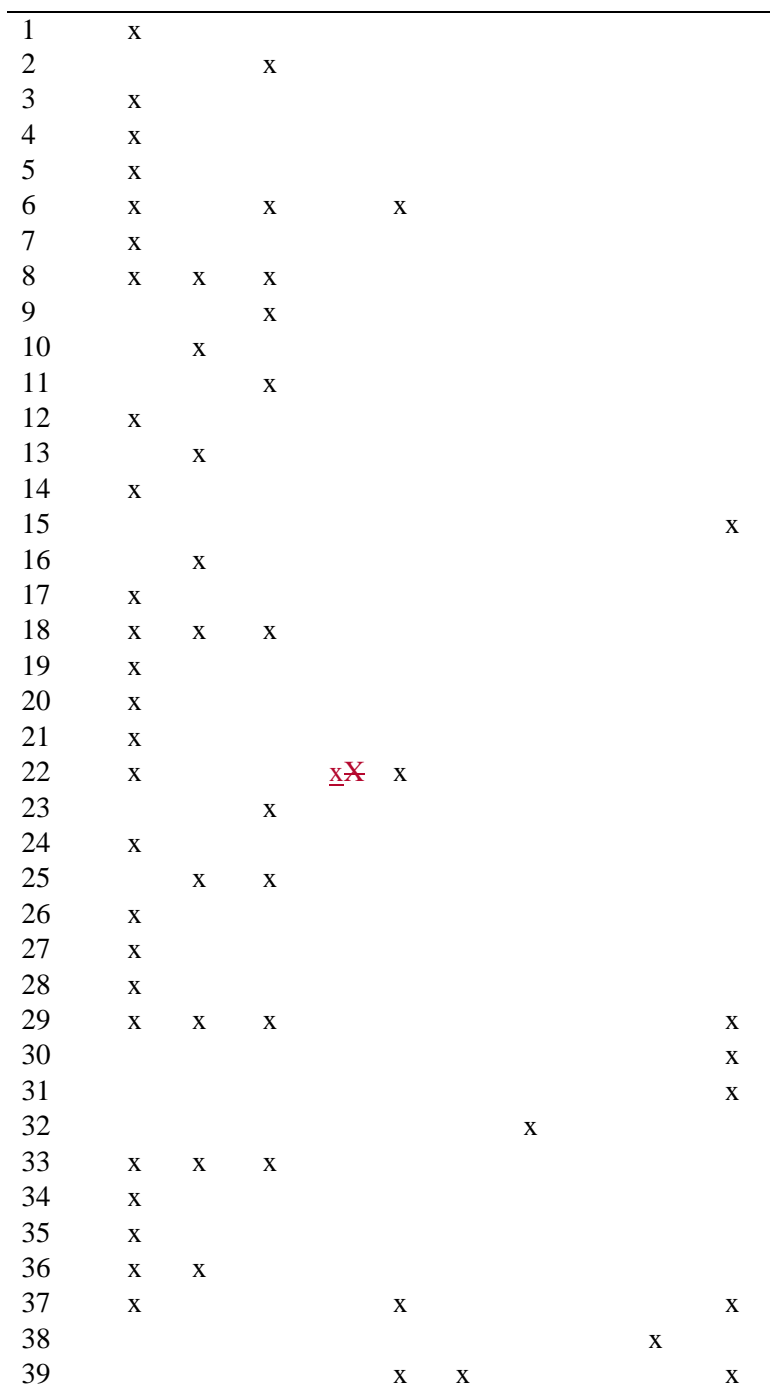




\begin{tabular}{|c|c|c|c|c|c|c|c|c|c|c|}
\hline & $\mathrm{x}$ \\
\hline \multicolumn{11}{|l|}{41} \\
\hline 42 & $\mathrm{x}$ & & & $\underline{x} \mathbb{X}$ & & $\mathrm{X}$ & & & & $\mathrm{x}$ \\
\hline 43 & & & & & & & & & & $\mathrm{x}$ \\
\hline 44 & & & & & $\mathrm{x}$ & & $\mathrm{x}$ & $\mathrm{x}$ & & $\mathrm{x}$ \\
\hline 45 & $\mathrm{x}$ & & & $\underline{\mathrm{x}} \mathrm{X}$ & & & & & & $x$ \\
\hline 46 & $\mathrm{x}$ & & & & & & & & & \\
\hline 47 & $\mathrm{x}$ & & & & & & & & & \\
\hline 48 & $\mathrm{x}$ & & & & & & & & & \\
\hline Total & 30 & 9 & 10 & 3 & 5 & 2 & 3 & 1 & 1 & 11 \\
\hline
\end{tabular}

Note: the numbers in the first column refers to those studies presented in Table 1 
Table 7 - Comparison of ffForecast a Accuracy

\begin{tabular}{|c|c|c|c|}
\hline Study & $\begin{array}{l}\begin{array}{l}\text { Forecasting } \\
\text { techniques }\end{array} \\
\end{array}$ & $\begin{array}{l}\text { Error } \\
\text { metric(s) }\end{array}$ & $\begin{array}{l}\text { Most accurate } \\
\text { technique }\end{array}$ \\
\hline Sklarz et al. (1987) & $\begin{array}{l}\text { Box-Jenkins } \\
\text { Auto-regressive }\end{array}$ & $\begin{array}{l}\text { MSE } \\
\text { MAPE }\end{array}$ & Auto-regressive \\
\hline Chang and Linneman (1990) & $\begin{array}{l}\text { Box-Jenkins } \\
\text { Trend }\end{array}$ & MAPE & Box-Jenkins \\
\hline Goh (1996) & $\begin{array}{l}\text { Regression } \\
\text { NN }\end{array}$ & $\begin{array}{l}\text { PE } \\
\text { MPE } \\
\text { MAPE }\end{array}$ & NN \\
\hline Goh (1998) & $\begin{array}{l}\text { Box-Jenkins } \\
\text { Regression } \\
\text { NN }\end{array}$ & $\begin{array}{l}\text { PE } \\
\text { MPE } \\
\text { MAPE }\end{array}$ & NN \\
\hline Goh (1999) & $\begin{array}{l}\text { Regression } \\
\text { Log-Regression } \\
\text { ANLR }\end{array}$ & $\begin{array}{l}\text { PE } \\
\text { MPE } \\
\text { MAPE }\end{array}$ & Log-Regression \\
\hline Goh (2000) & $\begin{array}{l}\text { NN } \\
\text { GA-NN }\end{array}$ & $\begin{array}{l}\text { PE } \\
\text { MPE } \\
\text { MAPE }\end{array}$ & GA-NN \\
\hline Fullerton et al. (2001) & $\begin{array}{l}\text { Box-Jenkins } \\
\text { Random walk } \\
\text { Structural }\end{array}$ & $\begin{array}{l}\text { Modified } U \\
\text { coefficient }\end{array}$ & Structural \\
\hline Ball and Tsolacos (2002) & $\begin{array}{l}\text { Box-Jenkins } \\
\text { Regression }\end{array}$ & $\begin{array}{l}\text { MAPE } \\
\text { RMSE }\end{array}$ & Box-Jenkins \\
\hline $\mathrm{Ng}$ et al. (2008b) & $\begin{array}{l}\text { Regression } \\
\text { GA-Regression }\end{array}$ & IS & GA-Regression \\
\hline Fan et al. (2010) & $\begin{array}{l}\text { Box-Jenkins } \\
\text { Regression }\end{array}$ & MAPE & Box-Jenkins \\
\hline Fan et al. (2011) & $\begin{array}{l}\text { Regression } \\
\text { VEC }\end{array}$ & $\begin{array}{l}\text { MAPE } \\
U\end{array}$ & VEC \\
\hline Jiang and Liu (2011) & $\begin{array}{l}\text { VEC } \\
\text { VEC-D }\end{array}$ & $\begin{array}{l}\text { MAPE } \\
U\end{array}$ & VEC-D \\
\hline Ng et al. (2011) & $\begin{array}{l}\text { Regression } \\
\text { VEC }\end{array}$ & $\begin{array}{l}\text { MAPE } \\
U\end{array}$ & VEC \\
\hline Jiang and Liu (2014) & $\begin{array}{l}\text { Regression } \\
\text { P-OLS } \\
\text { P-VEC }\end{array}$ & $\begin{array}{l}\text { MAPE } \\
U\end{array}$ & P-VEC \\
\hline Lam and Oshodi (2016a) & $\begin{array}{l}\text { Box-Jenkins } \\
\text { NN }\end{array}$ & $\begin{array}{l}\text { MAPE } \\
U\end{array}$ & $\mathrm{NN}$ \\
\hline Lam and Oshodi (2016b) & $\begin{array}{l}\text { Box-Jenkins } \\
\text { NN } \\
\text { SVM }\end{array}$ & $\begin{array}{l}\text { MAPE } \\
U\end{array}$ & SVM \\
\hline
\end{tabular}

Note: ANLR = autoregressive nonlinear regression; GA = genetic algorithm; NN = neural network; VEC $=$ vector error correction; VEC $-\mathrm{D}=$ vector error correction with dummy; P-OLS = panel ordinary least square; $\mathrm{P}-\mathrm{VEC}=$ panel vector error correction; $\mathrm{SVM}=$ support vector machine; $\mathrm{MSE}=$ mean squared error; $\mathrm{MPE}=$ mean percentage error; $\mathrm{MAPE}=$ mean absolute percentage error; $\mathrm{U}=$ Theil's inequality coefficient; IS = index sum 